\title{
COMMENTS
}

\section{LAND DEVELOPMENT, THE GRAHAM DOCTRINE, AND THE EXTINCTION OF ECONOMIC SUBSTANTIVE DUE PROCESS}

\section{ROBERT ASHBROOK ${ }^{\dagger}$}

INTRODUCTION.

I. CONSTITUTional PRotections OF LAND DEVElopmENT

RIGHTS

A. Substantive Due Process Claims

1. "Arbitrary and Capricious Substantive Due Process" Claims

2. "Substantive Due Process Takings" Claims

B. Regulatory Takings Claims..................................................... 1262

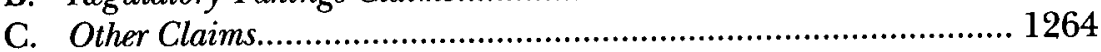

II. The CirCUIT SPLIT OVER THE GRAHAM DOCTRINE: WHERE CAN Substantive Due Process Be USED TO Challenge LAND DEVELOPMENT REGULATION?
A. The Graham Doctrine.

B. Armendariz and the Circuits Applying the Graham Doctrine to Takings Claims.

C. Circuits Applying the Graham Doctrine to SDP Takings Claims, but Not Arbitrary and Capricious SDP Claims.

D. Circuits Imposing Heightened Ripeness Requirements for Substantive Due Process Claims in Lieu of the Graham Doctrine

E. Circuits Ignoring the Graham Doctrine. 1274

F. The Seventh Circuit's Rejection of Substantive Due Process in Land Development Cases..

III. POTENTIAL EFFECTS OF THE GRAHAM DOCTRINE ON CHALLENGES TO LAND DEVELOPMENT REGULATION.

A. Procedural Differences.

${ }^{\dagger}$ S.B., 1983, Massachusetts Institute of Technology; J.D. Candidate 2002, University of Pennsylvania. The author thanks Garrett Broadrup, Thorne Clark, Alicia Hickok, Meghan Irmler, and Eric Kades for their thoughtful comments. 
2. Preclusion

3. Other Procedural Differences............................................... 1279

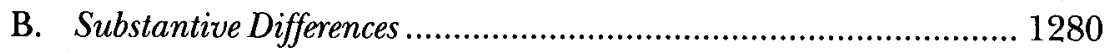

1. Takings That Do Not Violate Substantive Due Process

2. Substantive Due Process Violations That Are Not Takings

C. Remedial Differences.

IV. SubSTANTIVE Due Process Claims Should NOT LIE IN LAND

DEVELOPMENT CASES 1285

A. Federal Courts Should Abstain from Considering

Constitutional Claims by Land Developers

B. Graham Does Not Allow Substantive Due Process Claims by Land Developers. 1288

C. Addressing the Doctrinal Critics

D. A World Without Substantive Due Process Rights for

Land Developers.

E. Where the Supreme Court May Go ................................................ 1293

CONCLUSION.

\section{INTRODUCTION}

A developer seeks to build low-income housing in a middle-class suburb. She complies with the local zoning ordinance and all the permit regulations, but a citizens' group protests because it fears the subdivision will lower property values. The local government accedes and uses a pretext to reject the subdivision plan. Consequently, the developer loses her financing and her shirt. To avoid the expense and delay of an inverse condemnation suit for a regulatory taking in state court, she brings instead a substantive due process claim in federal court. This Comment concerns whether her substantive due process claim should lie.

As government's exercise of its police powers has grown over the last century, so too have those powers' conflicts with private property rights, particularly land development rights.' Zoning regulations, and later environmental regulations, became important legal weapons used by government to influence or limit private land development.

Initially, developers lacked potent constitutional protections

\footnotetext{
${ }^{1}$ While this Comment primarily focuses upon land development rights, many of the concepts are equally applicable to other property rights. But see infra Part IV.E (discussing the distinction between specific property interests and rights in all one's property that was made in Eastern Enterprises v. Apfel, 524 U.S. 498, 52437 (1998)).
} 
against such regulation. Traditional takings doctrine only protected against physical occupations of land; it did not apply to land use regulation. Later, landowners used two new doctrinal weapons-substantive due process and regulatory takings-to defend private property rights against government control.

In every other economic context, substantive due process and the legacy of Lochner $v$. New York ${ }^{2}$ has been discredited and extirpated. ${ }^{3}$ Thus it is strange that, until recently, federal courts have allowed economic substantive due process-an endangered species of constitutional doctrine-to escape extinction (and in some instances even to flourish) within the ecosystem that is land development law. ${ }^{4}$ Moreover, substantive due process survives despite its protections having been incorporated into regulatory takings doctrine, which might seem to vitiate the need for substantive due process. ${ }^{5}$ Substantive due process lives on largely because it retains one important evolutionary advantage over the takings doctrine: it provides a quick avenue into federal court for plaintiffs who would be delayed or discouraged by the strict ripeness requirements of regulatory takings claims.

While the Supreme Court has avoided this issue time and again," several circuits have applied a concept from constitutional criminal law, the "Graham doctrine," invalidating substantive due process

${ }^{2} 198$ U.S. 45 (1905).

${ }^{3}$ For example, the Supreme Court said in Ferguson v. Skrupa:

There was a time when the Due Process Clause was used by this Court to strike down laws which were thought unreasonable ... . The doctrine that prevailed in Lochner. . . has long since been discarded. . . . It is now settled that States "have power to legislate against what are found to be injurious practices in their internal commercial and business affairs, so long as their laws do not run afoul of some specific federal constitutional prohibition ...."

372 U.S. 726, 729-31 (1963) (emphasis added) (citation omitted).

Substantive due process does remain an important, albeit controversial, doctrine in the realm of "fundamental" rights regarding sex and the family. These occasionally may overlap with private property rights, see, e.g., Moore v. City of East Cleveland, 431 U.S. 494, 504-06 (1977) (favoring the right of families to live together over the city's zoning ordinance); however, economic rights generally, and private property rights specifically, are not themselves "fundamental." Cf. Ronald J. Krotoszynski, Jr., Fundamental Property Rights, 85 GEO. L.J. 555, 555-59 (1997) (advocating the creation of fundamental property rights).

${ }^{4}$ See, e.g., Michael J. Phillips, The Slow Retum of Economic Substantive' Due Process, 49 SYRACUSE L. REV. 917, 927-36 (1999) (citing examples of land use decisions).

${ }^{5}$ See infra Part I.B (discussing Agins $v$. City of Tiburon, 447 U.S. 255 (1980), and the incorporation of a means-ends calculus into takings doctrine).

${ }^{6}$ See infra notes 56-57 and accompanying text (citing cases).

${ }^{7}$ See Graham v. Connor, 490 U.S. 386, 395 (1989) (forbidding the use of substantive due process to enforce the explicit protections in the Fourth Amendment against 
claims by land developers challenging zoning and other regulations. The circuit courts of appeals are split on this issue, ${ }^{8}$ perhaps because it makes strange bedfellows of conservative supporters of private property rights and liberal supporters of unenumerated constitutional rights.

This Comment argues that the Graham doctrine should forbid substantive due process claims from supplementing or supplanting regulatory takings claims by land developer plaintiffs. Part I outlines substantive due process and regulatory takings. Part II describes the Supreme Court's Graham doctrine and the split of authority, in which some circuits apply the Graham doctrine to forbid substantive due process claims in regulatory takings cases and others do not. Part III compares three broad aspects of substantive due process claims and regulatory takings claims: procedural, substantive, and remedial. It also discusses how the Supreme Court has muddled the historical differences between the two claims. Finally, Part IV discusses the reasons why the Graham doctrine should be used to disallow all substantive due process claims where a regulatory takings claim is colorable against government regulation of land development.

\section{Constitutional Protections of LANd DeVElopment Rights}

\section{A. Substantive Due Process Claims}

Despite the end of the Lochner era early in the last century, substantive due process claims continue to succeed in land development cases. ${ }^{9}$ Such claims are generally brought under $\$ 1983^{10}$ for deprivations of property under the Fourteenth Amendment's Due Process Clause."

The Fourteenth Amendment, however, does not protect all putative property interests, nor all would-be development rights. Vested rights, those granted irrevocably, warrant protection. ${ }^{12}$ Alternatively, a

\footnotetext{
illegal seizures).

${ }^{8}$ See infra Part II (detailing the circuit split).

${ }^{9}$ See infra notes 103-06 (giving examples of cases where substantive due process claims were and were not successful).

${ }^{10} 42$ U.S.C. $\$ 1983$ (1994 \& Supp. V 1999).

11 "No State shall . . . deprive any person of life, liberty, or property, without due process of law." U.S. CONST, amend. XIV, \& 1.

${ }^{12}$ State law defines vested property rights. Typically, common law estops the government from changing the regulations applied to a developer after she expends significant amounts in good faith reliance on the old regulations. However, at least ten
} 
plaintiff developer must often show she is entitled to the use sought. ${ }^{13}$ Under an entitlement test, if government enjoys discretion in regulating development, a due process challenge will not lie. ${ }^{14}$ This is often a considerable hurdle for a plaintiff to cross.

Assuming a protectible property interest, a few courts ${ }^{15}$ and commentators ${ }^{16}$ have distinguished two types of substantive due process claims. The older are "arbitrary and capricious substantive due process" claims ("arbitrary and capricious SDP" claims), which allege irrational or ill-motivated government action. More recently, developers have asserted "substantive due process takings" claims ("SDP takings" claims), which are identical to takings claims, but which bypass the most difficult ripeness requirement of takings claims. It is sometimes difficult to distinguish between these two subspecies of substantive due process claims.

\section{1. "Arbitrary and Capricious Substantive Due Process" Claims}

Arbitrary and capricious SDP claims allege that government actions are not rationally related to legitimate objectives. These claims are descendants of the Lochner era, and they challenge regulation that is arbitrary or capricious.

states have statutes defining when vesting occurs, which can be as early as an initial subdivision application. See John Bredin, Vesting of Development Rights: A Primer, ZONING NEWS, July 1999, at 1 (listing statutes).

${ }^{13}$ See Thomas E. Roberts et al., Land-Use Litigation: Doctrinal Confusion Under the Fifh and Fourteenth Amendments, 28 URB. LAW. 765, 772-75 (1996) (criticizing yet recognizing the widespread use of the entitlement test). Not all circuits apply an entitlement test, however. In the Third Circuit, mere ownership of real property is enough to invoke due process against land use restrictions. See, e.g., DeBlasio v. Zoning Bd. of Adjustment, 53 F.3d 592, 601 (3d Cir. 1995) (noting additionally that "one would be hard-pressed to find a property interest more worthy of substantive due process protection than ownership"). This makes substantive due process claims much easier for developers to bring in the Third Circuit.

${ }_{4}$ See Zahra v. Town of Southold, 48 F.3d 674, 680 (2d Cir. 1995) (explaining the entitlement test). Read literally, an entitlement test is perhaps too stringent. A plaintiff who is genuinely entilled to a property right under state law may enforce her rights directly under that law, rather than indirectly through substantive due process.

${ }^{15}$ See, e.g., Bickerstaff Clay Prods. Co. v. Harris County; Ga., 89 F.3d 1481, 1490 n.16 (11th Cir. 1996) (distinguishing between substantive due process takings claims and arbitrary and capricious substantive due process claims); Pearson v. City of Grand Blanc, 961 F.2d 1211, 1215-16 (6th Cir. 1992) (same); Eide v. Sarasota County, 908 F.2d 716, 721-22 (11th Cir. 1990) (same).

${ }^{10}$ See, e.g., Roberts et al., supra note 13 , at $766 \&$ n.3 (distinguishing between substantive due process claims and due process takings); David S. Mendel, Note, Determining Ripeness of Substantive Due Process Claims Brought by Landowners Against Local Governments, 95 MICH. L. REV. 492, 492-93 n.4 (1996) (same). 
The precise level of substantive protection land developers could expect from arbitrary and capricious SDP claims has not always been clear. In 1926, the seminal zoning case of Village of Euclid $v$. Ambler Realty $C o$. defined unconstitutional regulation as "clearly arbitrary and unreasonable, having no substantial relation to the public health, safety, morals, or general welfare." This "substantial relationship" test allowed zoning regulation generally, as in Euclid, but sometimes invalidated individual zoning decisions. ${ }^{18}$

Since the 1930s, however, only "fundamental rights" have warranted serious scrutiny under substantive due process. ${ }^{19}$ Nevertheless, many courts of appeals continue to allow land developer plaintiffs to invoke arbitrary and capricious SDP claims. The precise legal standard varies by circuit. The District of Columbia Circuit merely requires a showing of "grave unfairness." ${ }^{20}$ More commonly, however, courts require some variation on arbitrariness and/or capriciousness. ${ }^{21}$

${ }^{17} 272$ U.S. 365,395 (1926).

${ }^{18}$ See, e.g., Nectow v. City of Cambridge, 277 U.S. 183, 188-89 (1928) (invalidating a particular zoning boundary).

${ }^{19}$ See Washington v. Glucksberg, 521 U.S. 702, 720 (1997) (listing cases involving sex and the family).

${ }^{20}$ Tri County Indus., Inc. v. District of Columbia, 104 F.3d 455, 459 (D.C. Cir. 1997) (citation omitted).

21 See, e.g., Lisa's Party City, Inc. v. Town of Henrietta, 185 F.3d 12, 17 (2d Cir. 1999) ("so outrageously arbitrary as to be a gross abuse of governmental authority" (citation omitted)); Sameric Corp. of Del. v. City of Philadelphia, 142 F.3d 582, 590 (3d Gir. 1998) ("arbitrary or capricious"); Hidden Oaks Ltd. v. City of Austin, 138 F.3d 1036, 1043 (5th Cir. 1998) ("unreasonable, or more to the point, arbitrary"); Bituminous Materials, Inc. v. Rice County, Minn., 126 F.3d 1068, 1070 (8th Cir. 1997) ("'something more than ... arbitrary [and] capricious" (quoting Chesterfield Dev. Corp. v. City of Chesterfield, 963 F.2d 1102, 1104 (8th Cir. 1992) (first alteration in original))); Sylvia Dev. Corp. v. Calvert County, Md., 48 F.3d 810, 827 (4th Cir. 1995) ("so arbitrary and irrational, so unjustified by any circumstance or governmental interest, as to be literally incapable of avoidance by any pre-deprivation procedural protections or of adequate rectification by any post-deprivation state remedies" (citation omitted)).

On the margins, however, the standards vary greatly. The Third Circuit has expanded greatly the reach of substantive due process by holding government action that is actually "' "motivated by bias, bad faith or improper motive,"” regardless of whether there is a conceivable legitimate motive, to be a substantive due process violation. $S a$ meric, 142 F.3d at 590-91 (quoting Parkway Garage, Inc. v. City of Philadelphia, 5 F.3d 685, 692 (3d Cir. 1993) (quoting Midnight Sessions, Ltd. v. City of Philadelphia, 945 F.2d 667, 683 (3d Cir. 1991))). (Perhaps the City of Philadelphia is often accused of bias, bad faith, or improper motive.) See also, e.g., Grant v. City of Pittsburgh, 98 F.3d $116,124-25$ (3d Cir. 1996) (holding that the intent of public officials is relevant); DeBlasio v. Zoning Bd. of Adjustment, 53 F.3d 592, 601-02 (3d Cir. 1995) (allowing a substantive due process claim when a zoning board's decision may have been influenced by one of its member's son's financial interest). 
Such standards indicate when a regulation fails a minimal means-ends test; that is, when the regulation is "not rationally related to a legitimate public purpose." ${ }^{22}$

\section{2. "Substantive Due Process Takings" Claims}

An SDP takings claim results when a regulation "goes too far and destroys the value of [one's] property to such an extent that it amounts to a taking by eminent domain without due process of law."23 Such a claim relies upon the theory that all takings without just compensation do not just violate the Takings Clause; they are also a deprivation of property that necessarily must violate the Due Process Clause. The elements of such a claim are identical to those of a regulatory takings claim, but an SDP takings claim conveniently avoids certain ripeness requirements needed to bring regulatory takings claims. $^{24}$

An SDP takings claim may be difficult to distinguish from an arbitrary and capricious SDP claim because both must allege failures of similar means-ends tests. The arbitrary and capricious SDP test (rationally related to a legitimate government purpose, often called "arbitrary and capricious") is quite similar to the SDP takings test borrowed from takings doctrine (substantially related to a legitimate

Occasionally, other circuits have recognized a similar standard in substantive due process cases, see, e.g., Bituminous Materials, 126 F.3d at 1071 ("[T] here may be cases where land use decisions are so corrupted by the personal motives of local government officials that due process rights are implicated."), although such claims seem better addressed under procedural due process.

Rarely, a municipal government that violates state or local law is also considered to have violated substantive due process rights of a plaintiff. See Roberts et al., supra note 13 , at 771-72 (citing cases and noting that such cases "demonstrate the problem of trying to cabin substantive due process once it is opened").

${ }^{22}$ WMX Techs., Inc. v. Gasconade County, Mo., 105 F.3d 1195, 1198 (8th Cir. 1997); see also, e.g., Tex. Manufactured Hous. Ass'n v. City of Nederland, 101 F.3d 1095, 1106 (5th Cir. 1996) ("The relevant inquiry for . . substantive due process . . . is whether there existed a rational basis for the City's [action].”); Sylvia Dev. Corp., 48 F.3d at 827 (relying on authority that allows a substantive due process claim against a zoning decision to survive only if "the alleged purpose [for the zoning decision] has 'no conceivable rational relationship' to ... the state's traditional police power"); Orange Lake Assocs. v. Kirkpatrick, 21 F.3d 1214, 1225 (2d Cir. 1994) (considering whether "the zoning ordinance in question [bore] anything other than a rational relationship to a legitimate government objective").

23 Pearson v. City of Grand Blanc, 961 F.2d 1211, 1215-16 (6th Cir. 1992).

${ }^{24}$ See Roberts et al., supra note 13, at $766 \mathrm{n} .3$ (noting also that "[ $\mathrm{t}$ ] his claim may be preferable to some since injunctive relief might be available"); infra Part III.A (describing procedural differences in challenges to land development regulation, including ripeness requirements). 
government purpose)..$^{25}$ Because the arbitrary and capricious SDP test is more stringent than the SDP takings test, ${ }^{26}$ arbitrary and capricious SDP violations are (substantively) necessarily both takings and SDP takings.

\section{B. Regulatory Takings Claims}

The Fifth Amendment guarantees, "nor shall private property be taken for public use, without just compensation." ${ }^{27}$ Its application to government regulation is a relatively recent aspect of constitutional jurisprudence, although it is generally considered to date from the 1922 decision of the Supreme Court in Pennsylvania Coal Co. v. Mahon: "while property may be regulated to a certain extent, if regulation goes too far it will be recognized as a taking." 28 Nevertheless, Mahon was decided in the Lochner era, and the Supreme Court at that time upheld land use regulation by applying the Fourteenth Amendment, not the Fifth. ${ }^{29}$

Regulatory takings came into their own in 1978 when Penn Central Transportation Co. $v$. New York City defined three factors in determining what was "too far": "the character of the governmental action," "the extent to which the regulation has interfered with distinct investmentbacked expectations," and "the economic impact of the regulation on the claimant." Later, the Supreme Court identified two per se regulatory takings ("physical occupations"31 and the "prohibit[ion of] all economically beneficial use of land"32) and clarified exactions, ${ }^{33}$ all of which are beyond the scope of this Comment.

${ }^{25}$ See infra Part I.B (exploring the "substantial relationship" test).

${ }^{26}$ See infra note 137 and accompanying text (distinguishing the two standards).

${ }^{27}$ U.S. CONST. amend. V.

28 260 U.S. 393, 415 (1922) (emphasis added).

${ }^{29}$ See Vill. of Euclid v. Ambler Realty Co., 272 U.S. 365, 397 (1926) ("The process applies with particular force to the solution of questions arising under the due process clause of the Constitution as applied to the exercise of the flexible powers of police, with which we are here concerned."); Steven J. Eagle, Del Monte Dunes, Good Faith, and Land Use Regulation, [2000] 30 Envtl. L. Rep. (Envtl. L. Inst.) 10,100, 10,106 (noting that Agins has its roots in substantive due process, not takings). But see Agins v. City of Tiburon, 447 U.S. 255, 260-61 (1980) (recharacterizing Euclid as a takings case).

${ }^{80} 438$ U.S. 104, 124 (1978).

${ }^{31}$ Loretto v. Teleprompter Manhattan CATV Corp., 458 U.S. 419, 441 (1982).

${ }^{32}$ Lucas v. S.C. Coastal Council, 505 U.S. 1003, 1029 (1992).

${ }^{33}$ Dolan v. City of Tigard, 512 U.S. 374 (1994); Nollan v. Cal. Coastal Comm'n, 483 U.S. 825 (1987). Exactions involve the government's demand that a landowner give up something (for example, money or an easement) in order to exercise her property rights. 
Euclid and other early cases upholding zoning regulations were based upon Lochneresque heightened scrutiny. It was not until 1980, in Agins $v$. City of Tiburon, ${ }^{34}$ that the Supreme Court took the opportunity to recharacterize its justification for upholding zoning generally. However, that recharacterization seemed to come out of left field: ${ }^{35}$ rather than change the 1920 s substantive due process test, the Court merely cut the "substantial relationship" language from Euclid" and pasted it into takings jurisprudence. Thus did Euclid and Nectow magically change from Fourteenth Amendment substantive due process cases into Fifth Amendment takings cases, ${ }^{37}$ and thus did a means-ends test enter into regulatory takings analysis.

The "substantial relationship" language of Agins goes beyond the mere rational basis review typically given substantive due process claims for economic harm. In Nollan, Justice Scalia wrote for the Court:

[O]ur verbal formulations in the takings field have generally been quite different [from those applied to substantive due process or equal protection claims]. We have required that the regulation "substantially advance" the "legitimate state interest" sought to be achieved, not that "the state 'could rationally have decided' that the measure adopted might achieve the State's objective."

Indeed, the Supreme Court seems to have specified an analysis that is a form of heightened scrutiny akin to Lochneresque substantive due process, at least for the means half of the test. It is not surprising, therefore, that the incorporation of heightened means-ends scrutiny into takings law has been vilified by scholars. ${ }^{39}$ Nevertheless, it re-

${ }^{34} 447$ U.S. 255 (1980).

${ }^{35}$ Perhaps it only came out of short left field. The Court had signaled this move two years earlier in Penn Central, 438 U.S. at 127, stating: "a use restriction on real property may constitute a 'taking' if not reasonably necessary to the effectuation of a substantial public purpose."

${ }^{36}$ Vill. of Euclid v. Ambler Realty Co., 272 U.S. 365, 395 (1926) (forbidding zoning ordinances that are "clearly arbitrary and unreasonable, having no substantial relation to the public health, safety, morals, or general welfare").

${ }^{37}$ See Agins, 447 U.S. at 260-61 (recharacterizing Nectow explicitly and Euclid by implication); see also City of Monterey v. Del Monte Dunes at Monterey, Ltd., 526 U.S. 687,753 (1999) (Souter, J., dissenting) (“[T]his Court cited a substantive due process case when recognizing the theory under the rubric of inverse condemnation.").

${ }^{38} 483$ U.S. at 834 n.3 (1987) (citations omitted).

${ }^{39}$ See, e.g., Lawrence Berger, Public Use, Substantive Due Process and Takings-An Integration, 74 NEB. L. REV. 843, 844 (1995) (“[U]nfortunately the Court has failed to maintain clear lines of demarcation between the substantive due process and takings rules and has introduced some unnecessary overlap and confusion in their application."); John D. Echeverria \& Sharon Dennis, The Takings Issue and the Due Process 
mains unclear if, in application, the "substantial relationship" analysis of regulatory takings actually differs from the "rational basis" test of substantive due process. ${ }^{40}$

The Court has invited this criticism by failing to give any theoretical justification for heightened scrutiny of regulatory takings. Nevertheless, heightened means-ends scrutiny for regulatory takings has now existed for more than two decades, and it has been reiterated again and again. ${ }^{41}$ Like it or not, we must assume that heightened means-ends scrutiny for takings is here to stay.

\section{Other Claims}

Other constitutional claims can be made in defense of development rights. They include equal protection claims, ${ }^{42}$ procedural due process claims, ${ }^{43}$ First Amendment claims, ${ }^{44}$ due process claims under

Clause: A Way Out of a Doctrinal Confusion, 17 VT. L. REv. 695, 696 (1993) ("The result is a confused body of law containing contradictory principles and standards."); Molly $\mathrm{S}$. McUsic, The Ghost of Lochner: Modern Takings Doctrine and Its Impact on Economic Legislation, 76 B.U. L. REV. 605, 667 (1996) (“[T] his Court is playing a role similar to that of the Lochner era Court: It is finding a significant portion of the liberal economic agenda unconstitutional."); Roberts et al., supra note 13, at 765-67 (discussing "problems caused by the failure to differentiate Fourteenth Amendment substantive due process claims from Fifth Amendment takings claims" and calling the situation an "unfortunate morass"); Edward J. Sullivan, Substantive Due Process Resurrected Through the Takings Clause: Nollan, Dolan, and Ehrlich, 25 ENVTL. L. 155, 155-56 (1995) ("A more sophisticated form of Lochner $v$. New York is upon us and . . results in the same difficulties presented in the Lochner era."); Glen E. Summers, Comment, Private Property Without Lochner: Toward a Takings Jurisprudence Uncorrupted by Substantive Due Process, 142 U. PA. L. REV. 837, 838 (1993) (“[T] he substantial relation test . . . [is] out of place in the field of takings jurisprudence ....").

These criticisms fall into four categories. First, heightened means-ends scrutiny is an exceedingly difficult standard to judge. Second, the means-ends analysis has no historical place in takings jurisprudence and is out of character with precedent. Third, because the remedies allowed by substantive due process and takings are different, so too should the analyses be different. Finally, the melding of substantive due process into takings jurisprudence invites the reemergence of Lochner-type judicial scrutiny of economic regulation.

${ }^{40}$ See, e.g., S. County Sand \& Gravel Co. v. Town of South Kingstown, 160 F.3d 834, 836 (1st Cir. 1998) (giving lip service to the different standards, but concluding that the tests are "congruent in this instance").

${ }^{41}$ See Del Monte Dunes, 526 U.S. at 721 (using language similar to Agins, 447 U.S. at 260); Dolan v. City of Tigard, 512 U.S. 374, 385 (1994) (citing the Agins formulation); Nollan v. Cal. Coastal Comm'n, 483 U.S. 825, 834 (1987) (same).

${ }^{42}$ See, e.g., Vill. of Willowbrook v. Olech, 528 U.S. 562, 565 (2000) (illustrating a homeowner's equal protection claim for an exaction).

${ }^{43}$ See, e.g., Nasierowski Bros. Inv. Co. v. City of Sterling Heights, 949 F.2d 890, 893 (6th Cir. 1991) (illustrating a procedural due process claim against a zoning decision). Some challenges to government actions seem to lie as either a procedural or substan- 
state constitutions, ${ }^{45}$ and takings claims under state constitutions. ${ }^{46}$ Such claims exist in harmony with both federal substantive due process and federal regulatory takings claims and do not alter the substance of this Comment.

Fifth Amendment substantive due process claims are also possible when a developer claims that the federal government unconstitutionally regulated land use, but they are much less common. However, analysis of Fifth Amendment due process claims is no different. ${ }^{47}$

The incorporation sense of the Fourteenth Amendment's Due Process Clause, ${ }^{48}$ occasionally referred to as "substantive due process," should not be confused with the wholly different sense of substantive due process at issue in this Comment. ${ }^{49}$

\section{THE CIRCUIT SPLIT OVER THE GRAHAM DOCTRINE: WHERE CAN SubSTANTIVE Due Process BE USED TO CHALlENGE LAND DEVELOPMENT REGULATION?}

Recall the hypothetical developer from the Introduction whose subdivision plan complied with the law but was denied by the local

tive due process claim. See, e.g., supra note 21 (discussing the Third Circuit's improper motivation standard).

${ }^{44}$ See, e.g., Alexander v. City of Minneapolis, 698 F.2d 936, 939 (8th Cir. 1983) (holding that a zoning ordinance aimed at adult bookstores violated the First Amendment).

${ }^{45}$ These may be confused with federal constitutional claims. See, e.g., Roberts et al., supra note 13, at 767-68 (noting the confusion between state and federal due process claims in Gerijo, Inc. v. City of Fairfield, 638 N.E.2d 533 (Ohio 1994)). However, where due process is treated identically, the question is moot. See, e.g., Vill. of Euclid v. Ambler Realty Co., 272 U.S. 365, 386 (1926) (concluding that due process rights under the Federal and Ohio Constitutions are the same).

${ }^{46}$ Sometimes, state constitutions provide greater takings protection than the federal Constitution. See, e.g., Bickerstaff Clay Prods. Co. v. Harris County, Ga. 89 F.3d 1481, 1491 (11th Cir. 1996) (allowing a takings claim under the Georgia Constitution, but not under the Fifth Amendment).

${ }^{47}$ See Tri County Indus. v. District of Columbia, 104 F.3d 455, 459 (D.C. Cir. 1997) (analyzing a Fifth Amendment case under a framework substantially identical to Fourteenth Amendment cases elsewhere).

${ }^{48}$ By itself, the Fifth Amendment's Takings Clause applies only to the federal government. Barron v. Mayor of Balt., 32 U.S. 242, 250, 7 Pet. 153, 159 (1833). It is applicable against a state or local government only by virtue of this "incorporation" sense of Fourteenth Amendment due process. S.D. Gas \& Elec. Co. v. San Diego, 450 U.S. 621, 623 n.1 (1981) (citing Chi., Burlington \& Quincy R.R., Co. v. City of Chicago, 166 U.S. 226, 239 (1897)).

${ }^{49}$ But see Dolan v. City of Tigard, 512 U.S. 374, 405-06 (1994) (Stevens, J., dissenting) (interpreting Chicago R.R. to be a Lochneresque substantive due process case rather than state incorporation of the Takings Clause). 
government for a reason unrelated to the merits. On similar facts, the Third Circuit recently upheld a developer's substantive due process claim. ${ }^{50}$ Four circuits allow such a claim without any relevant restrictions. ${ }^{51}$ In two circuits, arbitrary and capricious SDP claims are allowed, but SDP takings claims are prohibited. ${ }^{52}$ In two additional circuits, substantive due process claims are possible, but they are subject to the same strict ripeness requirements as takings claims, which makes them (as a practical matter) very unlikely. ${ }^{53}$ Three circuits prohibit substantive due process claims because they are subsumed into the Takings Clause by virtue of the Graham doctrine. ${ }^{54}$ Only the Seventh Gircuit may reject all such economic substantive due process claims because they are, like Lochner itself, inherently invalid. ${ }^{5}$

The Supreme Court has done little to resolve this circuit split; indeed, the Court may fairly be characterized as having encouraged it. ${ }^{56}$ Since the Lochner era, the Court has sidestepped the issue of whether substantive due process remains a valid rubric under which land development rights may be challenged. ${ }^{57}$ Perhaps this omission, along

${ }^{50}$ Woodwind Estates, Ltd. v. Gretkowski, 205 F.3d 118, 125 (3d Cir. 2000). Following the Third Circuit's decision, the local government quickly settled with the developer. Telephone Interview with Marshall E. Anders, Attorney, Woodwind Estates, Ltd. (Sept. 27, 2001).

${ }^{51}$ See infra Part II.E (Second, Third, Fourth, and Eighth Circuits).

${ }^{52}$ See infra Part II.C (Fifth and Eleventh Circuits).

${ }^{53}$ See infra Part II.D (Sixth and District of Columbia Circuits).

${ }^{54}$ See infra Part II.B (First, Ninth, and Tenth Circuits); infra Part II.A (explaining the Graham doctrine).

${ }^{55}$ Infra Part II.F.

State courts also vary in the extent to which they allow substantive due process claims to developers. Perhaps the most interesting is the State of Washington, where substantive due process is alive and well. See, e.g., Hugh D. Spitzer, Municipal Police Power in Washington State, 75 WASH. L. REV. 495, $511-17$ (2000) (explaining the reintroduction of substantive due process by Washington courts).

${ }^{56}$ See PFZ Props., Inc. v. Rodriquez, 503 U.S. 257 (1992) (dismissing a writ of certiorari previously granted in a substantive due process case brought by developer); Williamson County Reg'l Planning Comm'n v. Hamilton Bank, 473 U.S. 172, 185 (1985) ("The Court twice has left this issue undecided. Once again . . [it] must be left for another day." (citation omitted)); id. at 200 (reaching the same result "whether it is analyzed as a deprivation of property without due process under the Fourteenth Amendment, or as a taking under the Just Compensation Clause of the Fifth Amendment"); Echeverria \& Dennis, supra note 39, at 710 ("It is remarkable to observe that the Supreme Court has never addressed the relationship between the Due Process and the Takings Clauses squarely in its property jurisprudence.").

${ }^{57}$ See, e.g., Penn Cent. Transp. Co. v. New York City, 438 U.S. 104, 120-22 (1978) (holding that disallowing construction in the airspace above Grand Central Station was not a taking, but ignoring the substantive due process analysis upon which the New York Court of Appeals had reached the same conclusion below). But cf. Goldblatt v. 
with the incorporation of a substantive due process-like test into takings law and the universal condemnation of Lochner, are sending us a message about the Court's intentions. However, none of the circuit courts of appeals forbade substantive due process claims in land development rights cases until they received a big hint from the Supreme Court in Graham v. Connor.

\section{A. The Graham Doctrine}

In 1984, Dethorne Graham alleged that the police in Charlotte, North Carolina, stopped him and beat him up for no good reason. ${ }^{59}$ He brought a $\S 1983$ claim against the officers, alleging a violation of his constitutional rights, but he did not make clear the precise source of those rights. ${ }^{60}$ The Supreme Court considered both a Fourth Amendment seizure claim and a more general Fourteenth Amendment substantive due process claim, but it held that only the more specific Fourth Amendment claim would lie. ${ }^{61}$ Within the sphere of seizures, the Court said that the explicit protections of the Bill of Rights set the exclusive standard for what is constitutional. ${ }^{62}$

Graham seemed to apply only narrowly to Fourth Amendment seizure cases, but five years later in Albright $v$. Oliver, the Court reaffirmed and appeared to expand the scope of the Graham doctrine. ${ }^{63}$ The $A l-$ bright Court reasoned that where the Bill of Rights was incorporated to the states, the Framers' judgment constituted the extent of constitutional protection, not the more general provisions of the Fourteenth Amendment. "Where a particular Amendment 'provides an explicit textual source of constitutional protection' against a particular sort of government behavior, 'that Amendment, not the more generalized notion of "substantive due process," must be the guide for analyzing

Town of Hempstead, 369 U.S. 590, 594, 597 (1962) (contemplating a plaintiff's takings and due process claims, but deciding only the takings claim).

58490 U.S. 386 (1989).

59 $I$. at 388 .

${ }^{6} I d$. at 390 .

61 Id. at 395.

62 See id. at 394 ("The validity of the claim must then be judged by reference to the specific constitutional standard which governs that right, rather than to some generalized . . standard."); see also Whitley v. Albers, 475 U.S. 312, 326-27 (1986) (applying standards of the Eighth Amendment and passing over any general Fourteenth Amendment claim because the latter provides no greater protection).

${ }^{69}$ Albright v. Oliver, 510 U.S. 266, 273 (1994) (plurality opinion, with six Justices concurring in relevant part).

${ }^{64} I d$. 
these claims." "65 This language appears open ended, but Albright as a whole deals only with protections for criminal defendants in the Bill of Rights. ${ }^{66}$

The Supreme Court continues to leave open the question of a wider application of the Graham doctrine. As the Court recently noted:

[The Graham doctrine] does not hold that all constitutional claims relating to physically abusive government conduct must arise under either the Fourth or Eighth Amendments; rather, Graham simply requires that if a constitutional claim is covered by a specific constitutional provision, such as the Fourth or Eighth Amendment, the claim must be analyzed under the standard appropriate to that specific provision, not under the rubric of substantive due process.

This vague language hints at the application of Graham to invalidate substantive due process claims in civil suits regarding other aspects of the Bill of Rights. Some courts have taken this hint in other contexts, ${ }^{68}$ but land development cases are the bloodiest battleground in the war over the Graham doctrine.

\section{B. Armendariz and the Circuits Applying the Graham Doctrine to Takings Claims}

The Ninth Circuit is the leader in applying the Graham doctrine to takings cases. It first did so in a case brought by Thomas Armendariz and other owners of low-income housing in the Arden-Guthrie section San Bernardino, California, in 1991. ${ }^{69}$ They alleged that the city wanted to evict troublesome tenants in the neighborhood and to clear the area for a shopping center. ${ }^{70}$ To accomplish this, the city swept through the neighborhood citing landlords with seemingly minor building code violations and forcing tenants to move out until the violations were fixed. Moreover, the city refused to issue permits for the

${ }^{65}$ Id. (quoting Graham, 490 U.S. at 395 ).

${ }^{66} I d$. at 274-75. Although the Supreme Court refused to apply Graham to a civil case one year earlier, Soldal v. Cook County, Ill., 506 U.S. 56, 70-71 (1992), that case dealt with forbidding a Fourth Amendment claim because a substantive due process claim was possible, exactly the inverse of the holding in Graham.

${ }^{67}$ United States v. Lanier, 520 U.S. 259,272 n.7 (1997).

68 See, e.g., Gehl Group v. Koby, 63 F.3d 1528, 1535 n.8 (10th Cir. 1995) (First Amendment); Thorp v. Town of Lebanon, 612 N.W.2d 59, 77 (Wis. 2000) (equal protection).

${ }^{69}$ See Armendariz v. Penman, 75 F.3d 1311, 1313-15 (9th Cir. 1996) (en banc) (stating the facts alleged).

${ }^{70}$ Id. 
repairs, so property owners were either forced out of business for lack of rental income or for exceeding a 180-day vacancy time limit (after which the owners' grandfathered rental use would violate a new zoning ordinance). ${ }^{71}$ Armendariz brought suit claiming substantive due process violations.

The en banc decision in Armendariz reversed Ninth Circuit precedent $^{72}$ and applied the Graham doctrine to the Takings Clause; hence, Armendariz's substantive due process claim was barred. ${ }^{73}$ The court also concluded that, if Armendariz's allegations were true, they would constitute a private taking that was prohibited by the Takings Clause. ${ }^{74}$ Nevertheless, the opinion makes clear that a takings claim need not be successful to preempt a substantive due process claim. ${ }^{75}$ Instead, Armendariz merely seeks to prevent substantive due process from "expand [ing] the constitutional protections afforded by the Bill of Rights in those areas specifically addressed by the first eight amendments. Thus, Graham makes clear that the scope of substantive due process, however ill-defined, does not extend to circumstances already addressed by other constitutional provisions." ${ }^{, 76}$

The Ninth Circuit does not distinguish between arbitrary and capricious SDP claims and SDP takings claims. Indeed, it has applied Graham consistently to all economic substantive due process claims. ${ }^{77}$ Armendariz applies to both SDP takings claims and arbitrary and capricious SDP claims. Thus, by starting with Graham (Fourth Amendment seizures), applying its doctrine more generally in Albright (criminal protections in the Bill of Rights), and then analogizing in Amendariz

${ }^{71} I d$.

${ }^{72}$ See, e.g., Sinaloa Lake Owners Ass'n v. City of Simi Valley, 882 F.2d 1398, 1410 (9th Cir. 1989) (allowing a substantive due process claim despite a takings claim being unripe), overmuled by Armendariz, 75 F.3d at 1311.

${ }_{73}$ See Armendariz, 75 F.3d at 1324 ("Because the conduct that the plaintiffs allege is the type of government action that the Fourth and Fifth Amendments regulate, Graham precludes their substantive due process claims."). The merit of any potential substantive due process claim is irrelevant. Id. at 1326.

${ }^{74}$ Id. at 1322-24.

${ }^{75}$ Armendariz's takings claim failed because it was not ripe. Id. at 1325 n.10. Moreover, a takings claim need not even be brought in the first place for a substantive due process claim to be disallowed. See, e.g., Macri v. King County, 126 F.3d 1125, 1129 (9th Cir. 1997) ("[The plaintiffs] present[ed] essentially a takings claim under the claim of substantive due process ... . [They] cannot sidestep Armendariz by recharacterizing their claim as lying solely in substantive due process.").

${ }^{76}$ Armendariz, 75 F.3d at 1325.

77 See, e.g., Buckles v. King County, 191 F.3d 1127, 1138 (9th Cir. 1999) (concerning spot zoning); Macri, 126 F.3d at 1127 (concerning a "rule of thumb" limit on development characterized as "arbitrary and capricious" by the county court). 
(to Fifth Amendment takings), the Ninth Circuit has prohibited all substantive due process claims in land development cases in federal courts west of the Rockies.

The First Circuit has followed the lead of the Ninth. Although it previously had allowed substantive due process claims, ${ }^{78}$ the First Circuit reversed itself in 1998, noting that "the legal terrain has shifted considerably in the intervening years [since Smithfield in 1990]."79

Similarly, the Tenth Circuit probably considers substantive due process claims to be subsumed into the Takings Clause. ${ }^{80}$ Indeed, Miller preceded Armendariz by five years. However, the Tenth Circuit has seemed tentative recently in its adherence to the Graham doctrine for takings, casting doubt upon its earlier holdings. ${ }^{81}$

\section{Circuits Applying the Graham Doctrine to SDP Takings Claims, but Not Arbitrary and Capricious SDP Claims}

Two circuits distinguish between SDP takings claims, which they consider forbidden by (or subsumed into) the Takings Clause, and arbitrary and capricious SDP claims, which they permit.

The Eleventh Circuit makes this distinction explicitly. ${ }^{82}$ In Bicker-

${ }^{78}$ See, e.g., Licari v. Ferruzzi, 22 F.3d 344, 349-50 (1st Cir. 1994) (“[W]e have never announced a rule precluding district courts from finding substantive due process violations by land use planning officials in every conceivable case."); Smithfield Concerned Citizens for Fair Zoning v. Town of Smithfield, 907 F.2d 239, 241-42 (1st Cir. 1990) (recognizing a substantive due process challenge to a zoning ordinance but finding no violation); Urbanizadora Versalles, Inc. v. Rivera Rios, 701 F.2d 993 (1st Cir. 1983) (affirming a substantive due process judgment for a developer whose land was earmarked for condemnation, but not yet condemned after fourteen years).

${ }^{79}$ S. County Sand \& Gravel Co. v. Town of South Kingstown, 160 F.3d 834, 835 n.2 (1st Cir. 1998).

${ }^{80}$ See Bateman v. City of W. Bountiful, 89 F.3d 704, 709 (10th Cir. 1996) (holding due process and equal protection claims unripe because the takings claim into which they were "subsume[d]" was unripe); Miller v. Campbell County, 945 F.2d 348, 352-53 (10th Cir. 1991) (citing Graham for the proposition that a substantive due process claim is not permitted because it is "subsumed" in the Takings Clause, but seeming to limit that holding to the facts of the case).

${ }^{81}$ See Hyde Park Co. v. Santa Fe City Council, 226 F.3d 1207 (10th Cir. 2000) (relying upon nearly twenty-five-year-old precedent and a detailed analysis of the plaintiff's precise property interest to defeat a substantive due process claim, without mention of either Bateman or Miller).

${ }^{82}$ See Villas of Lake Jackson, Ltd. v. Leon County, 121 F.3d 610, 613-14 (11 th Cir. 1997) (stating that " $[\mathrm{t}]$ he notion of due process as an independent ground [for regulatory takings claims] has now been refuted," but also that "[a] landowner's vested rights created by state law may indeed constitute property subject to the arbitrary and capricious substantive due process protections under the federal Constitution"); Bickerstaff Clay Prods. Co. v. Harris County, Ga., 89 F.3d 1481, 1490 \& n.16 (11th Cir. 
staff, a brick manufacturer sought to have its land, initially zoned for agriculture, rezoned to allow a quarry. The county not only denied the manufacturer's request, but even took the opportunity to rezone the land for residential use only. Because the parcel was landlocked, this rendered it economically worthless. The court held that, because the issue was whether the rezoning was a valid exercise of the county's police powers, and because "the scope of 'public use' under the Takings Clause and the scope of 'police power' under the substantive component of the Due Process Clause are the same," ${ }^{, 83}$ Bickerstaff's due process claim was merely an SDP takings claim and hence subsumed into the Fifth Amendment.

In John Corp. v. City of Houston, the Fifth Circuit implicitly drew the same distinction as the Eleventh. ${ }^{84}$ John Corporation alleged that it wanted to rehabilitate fifty-three apartment buildings previously scheduled for demolition in Houston. ${ }^{85}$ After discussing its plans with the city and posting a seventy-thousand-dollar bond, John began the renovations. $^{86}$ However, the city evidently had a change of heart: it evicted all of John's tenants, went out of its way to thwart repair efforts, and then demolished many of the buildings. ${ }^{87}$

The court decided that John's takings claim did not necessarily forbid its substantive due process claim. "Instead, a careful analysis must be undertaken to assess the extent to which a plaintiff's substantive due process claim rests on protections that are also afforded by the Takings Clause ...." John's "careful analysis" is a test the vagueness of which is perhaps exceeded only by the "substantive" standard of substantive due process itself. It seems to prohibit SDP takings claims yet allow some sort of arbitrary and capricious SDP claims.

The Fifth Circuit failed to clarify the John test in Simi Investment Co. v. Harris County, Texas. ${ }^{89}$ Simi owned land near the Houston Astrodome that was separated from the street by a five foot wide, three thousand foot long county "park." The adjacent landowner, who was

1996) (holding that "Bickerstaff's Takings Clause claim subsumes its substantive due process claim" because Bickerstaff challenged the public purpose of the zoning decision, but noting that an arbitrary and capricious SDP claim "is not foreclosed by the Takings Clause").

${ }^{83}$ Bickerstaff, 89 F.3d at 1490 .

${ }^{84} 214$ F.3d 573, 585 (5th Cir. 2000).

${ }^{85}$ Id. at 575.

${ }^{86}$ Id.

${ }^{87} \mathrm{Id}$.

${ }^{88} I d$. at 583 .

${ }^{89} 236$ F.3d 240 (5th Cir. 2000). 
a county official, allegedly caused Simi to be denied the right to cross the five foot wide "park" so Simi could not interfere with the official's business-operating the stadium. Simi won its arbitrary and capricious SDP claim after a "careful analysis," which the court only clarified by stating that "when a state interferes with property interests, a substantive due process claim may survive a takings analysis."

These two circuits' interpretation is, in the end, little different from the circuits that do not restrict substantive due process claims. If the takings claim is ripe, then any violation of substantive due process necessarily will be a taking ${ }^{91}$ and hence prohibited as an SDP takings claim. But when the substantive due process claim is ripe and the takings claim is not, ${ }^{92}$ an arbitrary and capricious SDP claim is possible. This implies that the due process claim will only lie if the plaintiff has not sought compensation. This was the exact situation in Simi.

\section{Circuits Imposing Heightened Ripeness Requirements for Substantive Due Process Claims in Lieu of the Graham Doctrine}

Two circuits have refused to apply the Graham doctrine as the Ninth Circuit did in Amendariz: the D.C. Circuit explicitly ${ }^{93}$ and the Sixth Circuit implicitly. ${ }^{94}$ However, perhaps sympathetic to the result in Armendariz, each has disqualified substantive due process claims on another ground-that they did not meet the very same strict ripeness requirements that are required of regulatory takings. In doing so, the primary reason for bringing a substantive due process claim is eliminated. Thus, while these circuits do not uphold Armendariz and Graham in form, they do so in substance.

In Montgomery, the Sixth Circuit disagreed with its prior precedent

${ }^{90}$ Id. at 249.

91 Supra text accompanying note 24.

${ }^{92}$ See infra Part III.A.1 (explaining that takings claims must satisfy two prongsfinality and compensation-to be ripe, while arbitrary and capricious SDP claims merely need to satisfy the finality prong).

${ }^{93}$ See Tri County Indus., Inc. v. District of Columbia, 104 F.3d 455, 459 (D.C. Cir. 1997) ("But in this circuit at least, ... the requirements of the [T]akings [C]lause cannot be said to exhaust the Fifth Amendment's substantive protection of property rights from government imposition.").

${ }^{94}$ Montgomery v. Carter County, Tenn., 226 F.3d 758, 768-70 (6th Cir. 2000) (acknowledging Armendariz but refusing to rely upon it); cf. Choate's Air Conditioning \& Heating, Inc. v. Light, Gas \& Water Div., No. 00-5399, 2001 U.S. App. LEXIS 14777, at *17-20 (6th Cir. June 22, 2001) (implying in dicta that an arbitrary and capricious SDP claim might be allowed). 
allowing most substantive due process claims. ${ }^{95}$ It signaled that it would no longer accept the use of substantive due process claims before the ripeness requirements of a takings claim are met. ${ }^{96}$

The District of Columbia Circuit is not normally a hotbed of land development litigation, but it considered the issue in Tri County Industries, Inc. $v$. District of Columbia. ${ }^{97}$ There, the plaintiff obtained all the building permits and licenses required to convert an empty warehouse in Washington and to operate it as a hazardous materials decontamination facility. ${ }^{98}$ But as public opposition to the facility grew, the District responded by suspending both Tri County's building permit and its air quality permit.

Although Tri County's takings claim against the District was not ripe because it had never sought just compensation, the court independently considered Tri County's substantive due process claim. The court went on, however, to hold that virtually the same ripeness requirement also applies to substantive due process claims. ${ }^{100}$ Unlike the Sixth Circuit, which offered no basis whatsoever for its substantive due process ripeness requirement, the D.C. Circuit purported to find its ripeness requirement implicitly or explicitly in the substantive content of the Due Process Clause. ${ }^{101}$

Imposing a similar ripeness requirement upon both substantive due process and regulatory takings is attractive because it eliminates the primary motivation for bringing a substantive due process claims as opposed to takings claims. But therein lies the fatal flaw with the Sixth and D.C. Circuits' formulation, at least with regard to arbitrary

${ }^{95}$ Specifically, dicta in Montgomery disagreed with the Sixth Circuit's earlier didactic opinion in Pearson v. City of Grand Blanc, 961 F.2d 1211, 1215 (6th Cir. 1992), which called the existence of an unlawful zoning action the only ripeness requirement for a substantive due process claim. Montgomery, 226 F.3d at 768-70. Ironically, the Pearson court had criticized the district court below for the precise holding the appellate court itself adopted in Montgomery just eight years later. See Pearson, 961 F.2d at 1215 ("By holding that the taking theory subsumes all other theories in zoning cases, the trial court in the instant case would impose these stringent ripeness requirements on all zoning cases.").

${ }_{96}$ Montgomery, however, leaves open the possibility of a substantive due process claim if a takings claim is also ripe. $226 \mathrm{~F} .3 \mathrm{~d}$ at 769-70 (" $[\mathrm{S}]$ ubstantive due process ... may not be used in order to mount an end run around the ripeness requirements [for takings claims]."); see also Choate's, 2001 U.S. App. LEXIS 14777, at *20-21 (requiring an inverse condemnation suit before any constitutional violation is ripe).

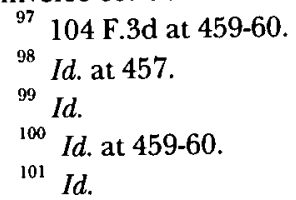


and capricious SDP claims: unlike takings doctrine, there is simply no basis for these circuits' odd requirement that a plaintiff must seek a compensation remedy before bringing substantive due process claim. $^{102}$ The Constitution forbids violations of due process regardless of whether they are compensated or not and there is no compensation ripeness requirement to bring substantive due process claims for any liberty interest that may be infringed. Forbidding substantive due process claims is the correct result, but using ripeness requirements is the wrong way to get there for arbitrary and capricious SDP claims.

\section{E. Circuits Ignoring the Graham Doctrine}

While Armendariz has gained adherents in the circuit courts of appeals in recent years, four circuits have not restricted substantive due process claims in land development rights cases. These circuits have yet to address Armendariz and the Graham doctrine. They include the Second, ${ }^{103}$ Third, ${ }^{104}$ Fourth, ${ }^{105}$ and Eighth ${ }^{106}$ Circuits. Because these

${ }^{102}$ The D.C. and Sixth Circuits' ripeness requirement is correct for SDP takings claims if one assumes that those claims are legitimate to begin with.

${ }^{103}$ See Lisa's Party City, Inc. v. Town of Henrietta, 185 F.3d 12, 17 (2d Cir. 1999) (allowing a substantive due process claim, but holding that it failed); Vill. Pond, Inc. v. Town of Darien, 56 F.3d 375, 377-79 (2d Cir. 1995) (permitting a builder's substantive due process challenge to the town's decision not to allow two condominiums to be occupied unless the builder sold them to the town); Sullivan v. Town of Salem, 805 F.2d 81, 85 (2d Cir. 1986) (stating that prohibiting the occupancy of a new home which meets the building code, when the building official has no discretion beyond that issue, is a deprivation of property without due process).

${ }^{104}$ The Third Circuit is the most liberal in the country in allowing substantive due process claims for developers. See Woodwind Estates, Ltd. v. Gretkowski, 205 F.3d 118, 120-22, 125 (3d Cir. 2000) (reversing dismissal of plaintiff's substantive due process challenge to the denial of its application for subdivision approval); Blanche Rd. Corp. v. Bensalem Township, 57 F.3d 253, 254 (3d Cir. 1995) (reversing judgment as a matter of law for the government); DeBlasio v. Zoning Bd. of Adjustment, 53 F.3d 592, 593 (3d Cir. 1995) (reversing summary judgment for the government); Bello v. Walker, 840 F.2d 1124, 1128 (3d Cir. 1988) (same); $c f$. Herr v. Pequea Township, 274 F.3d 109, $127 \&$ n.3 (3d Cir. 2001) (Garth, J., dissenting) (recognizing that Albright v. Oliver, 510 U.S. 266 (1994), may invalidate a claim of "a malicious use of civil process claim in violation of [the] 14th Amendment," but nevertheless arguing that a substantive due process claim still exists).

${ }^{105}$ See Front Royal \& Warren County Indus. Park Corp. v. Town of Front Royal, Va., 135 F.3d 275, 287-88 (4th Cir. 1998) (allowing a substantive due process claim, but holding that it failed); Sylvia Dev. Corp. v. Calvert County, Md., 48 F.3d 810, 827 (4th Cir. 1995) (same); Marks v. City of Chesapeake, Va., 883 F.2d 308, 313 (4th Cir. 1989) (holding that withholding a permit for a palm reading business for religious reasons is arbitrary and capricious and violates due process).

${ }^{106}$ See Rozman v. City of Columbia Heights, 268 F.3d 588, 592-93 (8th Cir. 2001) (allowing a substantive due process claim, but holding that it failed); Bituminous Ma- 
circuits fail to apply the Graham doctrine, "[w]e may conclude that these courts view[] the substantive due process claims before them as asserting rights not protected by the Takings Clause."107

\section{F. The Seventh Circuit's Rejection of Substantive Due Process in Land Development Cases}

Substantive due process for land development regulation claims is simply a non-starter in the Seventh Circuit. Judge Frank Easterbrook's opinion in Gosnell v. City of Troy, Illinois, refers to substantive due process as an "oxymoron" and takes pains to remind us that "[e]conomic substantive due process is not just embattled; it has been vanquished." 108 Thus, in federal court in Illinois, Indiana, and Wisconsin, land development regulation simply cannot be invalidated with a substantive due process claim; instead, the remedy is compensation through a takings claim. ${ }^{109}$ "A municipality may bring . . . development to a halt for strong reasons or weak reasons. If the latter, the municipality has to pay for the privilege. But act it may. Businesses must make their arguments under the [T]akings [C]lause ...."110

But even the Seventh Circuit now hedges its bet. In Forseth $v$. Village of Sussex, the court "recognized the potential for a plaintiff to maintain a substantive due process claim in the context of land use decisions." "111

Is Judge Easterbrook the only one who remembers that Lochner

terials, Inc. v. Rice County, Minn., 126 F.3d 1068, 1070-71 (8th Cir. 1997) (same); Alexander v. City of Minneapolis, 698 F.2d 936, 936-37 (8th Cir. 1983) (finding a 14th Amendment violation in substantially restricting access to adult bookstores through a zoning ordinance that would have put seven to nine of the ten adult bookstores in the city out of business).

${ }^{107}$ John Corp. v. City of Houston, 214 F.3d 573, 583 (5th Cir. 2000).

10859 F.3d 654, 657 (7th Cir. 1995). Procedural due process is likewise "a redundancy." Id. Judge Easterbrook does, however, recognize two legitimate theories that share a similar foundation with economic substantive due process: the protection of fundamental liberty interests and the incorporation of the Bill of Rights to the states. Id. at 657-58.

${ }^{109}$ Seeking compensation for an alleged taking not acknowledged by the government is referred to as "inverse condemnation." Agins v. City of Tiburon, 447 U.S. 255, 258 n.2 (1980).

${ }^{110}$ Gosnell, 59 F.3d at 657 (citations omitted); see also McKenzie v. City of Chicago, 118 F.3d 552, 558 (7th Cir. 1997) (Easterbrook, J.) ("If it is willing to pay the piper, Chicago may call the tune free from any objection based on 'substantive due process." ").

199 F.3d 363, 368-69 (7th Cir. 2000) (listing cases contrary to Gosnell). 
was "vanquished"?" Perhaps not. But as the spilled ink on this topic surely suggests, later generations have forgotten the sacrifices of the generation that went to war against economic substantive due process.

\section{Potential EFFECTS OF THE GRAHAM Doctrine on CHALlENGES TO LAND DEVELOPMENT REGULATION}

If the Graham doctrine extends to the Takings Clause, as the Ninth Circuit held in Armendariz, then substantive due process claims will be unavailable to developer plaintiffs, who will have to allege regulatory takings instead. The effect of using Graham in this way is best understood by examining the differences between substantive due process claims and regulatory takings claims, including the different claims' effects on plaintiffs' litigation strategies and chances for success. $^{113}$

These differences may be grouped into three loosely defined categories-procedural, substantive, and remedial. Among the procedural differences, the most significant is ripeness, which makes getting into federal court much more difficult for takings plaintiffs. Substantive differences, however, make regulatory takings claims (theoretically) easier to win because of the somewhat heightened level of means-ends scrutiny employed. Finally, although the available remedies vary, the differences are smaller than they may first appear.

\section{A. Procedural Differences}

The procedural differences between takings and substantive due process claims may significantly affect the choice of tactics employed by a plaintiff. Ripeness is a major hurdle for a would-be takings plaintiff attempting to state a claim; hence, due process claims are often faster and less expensive to make. Preemption, the availability of a jury trial, and forum differences may also be of concern.

\section{Ripeness}

Williamson County Regional Planning Commission v. Hamilton Bank of

112 Lochner has never been formally overruled. But cf. supra note 3 (quoting Ferguson v. Skrupa, 372 U.S. 726, 729-31 (1963), which indicates the Supreme Court's opinion that the Lochner doctrine has been "discarded").

${ }^{113}$ See Karena C. Anderson, Comment, Strategic Litigating in Land Use Cases: Del Monte Dunes v. City of Monterey, 25 EcOLOGY L.Q. 465 (1998) (considering litigants' reasons for pursuing a substantive due process claim or a takings claim or both). 
Johnson City $^{114}$ sets forth the two-pronged federal ripeness requirement for regulatory takings. ${ }^{115}$ The first is a finality prong: "a claim that the application of government regulations effects a taking of a property interest is not ripe until the government entity charged with implementing the regulations [under which the property was "taken"] has reached a final decision regarding the application of the regulations to the property at issue."116 The finality prong serves several purposes, including developing of a factual record and preventing garden variety zoning conflicts from becoming federal cases. ${ }^{117}$ How far a developer must go is not precisely stated, but it seems clear that in zoning cases, both an initial application and a variance application must be denied. $^{118}$ Multiple applications are also required to perfect a regulatory takings claim. ${ }^{119}$ Generally, the finality prong is the easier of the two ripeness prongs for a plaintiff to meet; the time and cost involved in submitting zoning applications are often low compared to an inverse condemnation suit. However, revised applications to development plans can nevertheless involve costly architectural, engineering, and legal fees.

Second is a compensation prong. A takings claim against a state also requires the plaintiff to have unsuccessfully sought just compensation through a procedure established by the state (typically, an inverse condemnation suit). ${ }^{120}$ The Fifth Amendment is not violated by a mere taking; a taking must be uncompensated before a federal con-

114473 U.S. 172 (1985).

${ }^{115}$ The Williamson County ripeness doctrine does not apply to the extent a plaintiff claims property was taken for a private use. See Montgomery v. Carter County, Tenn., 226 F.3d 758, 767 (6th Cir. 2000) (concluding that the weight of authority supports this result). Hence, substantive due process claims would not enjoy this major advantage over "private takings" claims. Cf. Bickerstaff Clay Prods. Co. v. Harris County, Ga., 89 F.3d 1481, 1490 \& n.16 (11th Cir. 1996) (holding that a private takings claim subsumed an SDP takings claim).

${ }_{116}$ Williamson County, 473 U.S. at 186.

117 Anderson, supra note 113, at 471; see also Taylor Inv., Ltd. v. Upper Darby Township, 983 F.2d 1285, 1291 (3d Cir. 1993) (noting the rationale for the finality prong in zoning cases).

II Williamson County, 473 U.S. at 187-88; see also Mendel, supra note 16, at 497-98 (explaining the different interpretations taken by the circuit courts of appeals when applying the ripeness doctrine to substantive due process).

${ }_{119}$ See Penn Cent. Transp. Co. v. New York City, 438 U.S. 104, 136-37 (1978) (indicating that rejection of two plans for alterations to plaintiff's property did not mean that the city would deny all plans).

${ }^{120}$ Williamson County, 473 U.S. at 194-95. Similarly, takings claims against the federal government must meet the requirements of the Tucker Act, 28 U.S.C. $\$ 1491$ (1994). 473 U.S. at 195. 
stitutional claim is ripe. The compensation prong reflects the view that a plaintiff must give the state the opportunity to identify and compensate a regulatory taking before literally making a federal case out of the situation. Unfortunately for plaintiffs, the practical effect of the compensation prong is often to require lengthy and expensive litigation before a federal takings claim can be heard.

The ripeness of an arbitrary and capricious SDP claim is also subject to the finality prong of Williamson County. ${ }^{121}$ However, the more onerous compensation prong is not required. ${ }^{122}$ Because the Constitution does not give government the option of merely compensating violations of due process (unlike takings), there is generally no need to seek compensation through state-mandated procedures before an arbitrary and capricious SDP claim is ripe. ${ }^{123}$ This is the great advantage of a due process claim, and it is often the motivation behind developers' substantive due process claims. Hence, in jurisdictions where the Graham doctrine is used to prohibit substantive due process claims, developers find it more difficult to ever get into federal court.

\section{Preclusion}

If a plaintiff in a jurisdiction allowing both types of claims chooses only to pursue a takings claim, she may lose any opportunity for a substantive due process claim that she might have had. The inverse condemnation litigation required of federal takings claims by the compensation prong of Williamson County may preclude any subsequent substantive due process claim. ${ }^{124}$ Most state courts try the constitu-

121473 U.S. at 199. Although the circuit courts of appeals have interpreted the precise definition of what constitutes a final decision differently, Mendel, supra note 16, at 497-98; Anderson, supra note 113, at 472-73, there is no evidence that the criteria are any different for takings and substantive due process claims. See Forseth v. Vill. of Sussex, 199 F.3d 363, 368-70 (7th Cir. 2000) (rejecting prior Seventh Circuit precedent that indicated a difference).

${ }^{122}$ But see supra Part II.D (noting that two circuits impose the same ripeness requirements upon substantive due process claims as on takings claims).

${ }^{123}$ But see Anderson, supra note 113, at 473 \& n.32 (noting First Circuit cases where a state inverse condemnation suit was required to be resolved before a substantive due process claim was ripe). These cases, however, were decided before the First Circuit adopted the Graham doctrine.

124 Also, a federal takings claim itself may be precluded by the same state inverse condemnation suit. See generally Kathryn E. Kovacs, Accepting the Relegation of Takings Claims to State Courts: The Federal Courts' Misguided Attempts to Avoid Preclusion Under Williamson County, 26 ECOLOCY L.Q. 1, 14 (1999) ("Since the legal and factual issues in the state and federal takings cases are often similar, if not identical, the plaintiff who files first in state court is usually precluded from litigating a federal takings claim in 
tional issues in the same proceeding, ${ }^{125}$ making any substantive due process claim subject to claim preclusion..$^{126}$ Even if such a claim can be preserved, the issues of fact involved are very similar, ${ }^{127}$ raising the possibility of issue preclusion of a later due process claim. ${ }^{12}$

Therefore, if Graham does not preclude a substantive due process claim altogether, a plaintiff faces three choices. First, she may pursue both inverse condemnation and substantive due process claims together in state court, which is often an undesirable forum for the due process claim. Second, she may pursue only the inverse condemnation claim in state court, and take her chances on the delay and potential preclusion of a subsequent substantive due process claim in federal court. Third, she may put off the inverse condemnation claim (or litigate it in a parallel proceeding) while pursuing a substantive due process claim in federal court, where it may elicit a better reception. The third alternative is often the most attractive to a developer plaintiff, although it may result in duplicative litigation.

\section{Other Procedural Differences}

The right to a jury trial under the Seventh Amendment may be different for substantive due process claims and takings claims, depending upon the forum. ${ }^{129}$ Substantive due process claims are generally decided without a jury. ${ }^{130}$ Similarly, takings liability was historically reserved for a judge, while the amount of compensation was decided by a jury. Del Monte Dunes liberalized this rule of thumb. ${ }^{131}$ Now, for claims that all economically viable use has been taken, a jury may decide liability. In addition, some fact-intensive claims that a tak-

federal court.").

${ }_{125}$ Stuart Minor Benjamin, Note, The Applicability of Just Compensation to Substantive Due Process Claims, 100 YALE L.J. 2667, 2676 n.52 (1991).

${ }^{126}$ Anderson, supra note 113, at 476.

${ }^{127}$ See supra Part I.A.2 (explaining that both claims involve a means-ends analysis).

${ }^{128}$ See Anderson, supra note 113, at 474 ("[A] landowner plaintiff who particularly desires a federal forum for her claim may be limited to a substantive due process theory of recovery.").

${ }_{129}$ The Seventh Amendment's right to a jury trial does not apply to suits brought against the federal government, suits brought in state court (including inverse condemnation suits), or suits seeking only injunctive relief. See City of Monterey v. Del Monte Dunes at Monterey, Ltd., 526 U.S. 687, 719 (1999) (citing takings cases).

${ }^{130}$ See id. at 753 (Souter, J., dissenting) ("Substantive due process claims are, of course, routinely reserved without question for the court.").

${ }^{131}$ See id. at 711-22 (recognizing that traditional judge and jury roles are not easily demarcated in regulatory takings cases). 
ing is not in the public interest may also be decided by a jury. ${ }^{132}$

The availability of a substantive due process claim may affect the choice of forum. For example, while Armendariz is binding upon federal courts in the state of Washington, it is not binding upon state courts in Washington. Plaintiffs in the State of Washington who wish to bring substantive due process claims undoubtedly would prefer to bring their federal claims in state court. ${ }^{133}$

\section{B. Substantive Differences}

"While Fifth Amendment takings law often carries labels such as confused and complex, one doctrinal mess that goes beyond those terms into the realm of the truly maddening is the jumbled distinction between Fifth Amendment takings claims and Fourteenth Amendment substantive due process claims." The difference between the two claims is best illustrated in examining situations where only a taking occurs (which is not a violation of due process) and situations where only a violation of substantive due process occurs (which is not a taking). SDP takings claims need not be considered because they allege elements identical to regulatory takings claims; only arbitrary and capricious SDP claims need be examined.

\section{Takings That Do Not Violate Substantive Due Process}

Where a regulatory taking occurs that is not a violation of substantive due process, there must be some substantive element for the taking that is more stringent than, or not present in, a due process analysis. Examples include physical occupations, losses of all economic value, and certain exactions. ${ }^{195}$ Most significantly, they also include the "substantial relationship" means-ends analysis of Agins, which Justice Scalia has insisted is stricter than the "rational basis review" generally afforded substantive due process claims. ${ }^{136}$

Regarding the "means" portion of the two types of means-ends

${ }^{132}$ See id. at 720-21 (recognizing that questions of whether land-use decisions advance the public interest are largely fact-bound and are properly addressed to a jury).

${ }^{133}$ See, e.g., Guimont v. Clarke, 854 P.2d 1 (Wash. 1993) (illustrating a successful substantive due process claim made in state court that would have been dismissed had it been brought in federal court after Armendariz).

134 Roberts et al., supra note 13, at 766.

${ }^{135}$ See supra Part I.B (outlining takings doctrine).

${ }^{136}$ Supra note 38 and accompanying text. But see Vill. of Arlington Heights v. Metro. Hous. Dev. Corp., 429 U.S. 252, 263 (1977) (noting "the generous Euclid test"). 
analyses, two types of claims seem to fall into Justice Scalia's theoretical gap between the different levels of scrutiny. First, the terms "rational" and "substantial" infer a difference of degree within which at least some government regulation could be rationally related (satisfying substantive due process) yet not substantially related (hence a taking) to the government purpose. However, "the Court's precedents have not elaborated on the exact type of connection between a regulation and a state interest that is necessary to constitute a 'substantial relation,' let alone defined precisely the difference between the substantial relation test and rationality review." ${ }^{137}$ In practice, the number of claims falling between the two levels of scrutiny is vanishingly small.

Conceptually, however, the takings test presumably does not permit the merely conceivable basis for government regulation that "rational basis review" allows for substantive due process; it appears to require that the government actually have a substantial relationship in mind while regulating. If so, then regulation actually motivated by bad faith (for example, personal gain of the regulator or dislike of the landowner) or considerations other than the merits would appear to be a taking, while such regulation is not usually a due process problem where some other legitimate pretext can be found. ${ }^{138}$

Regarding the "ends" analysis, it is not at all clear that there is any difference between the takings test and the substantive due process test. The scope of legitimate ends for the purpose of substantive due process has been held identical to the "public use" requirement of traditional takings analysis, ${ }^{139}$ and the Supreme Court has not indicated that the ends in an Agins means-ends analysis are any different from the ends in more traditional takings jurisprudence.

Unlike due process claims, takings claims have no threshold "protected property interest" requirement. Because a difficult-to-meet entitlement test is often used to define the protected property interest, takings claims may be, substantively, easier to win. This is particularly true where discretionary use permitting and zoning variances are commonplace. However, takings claims have their own significant threshold barrier in Williamson County's compensation prong for ripe-

${ }^{187}$ S. County Sand \& Gravel Co. v. Town of South Kingstown, 160 F.3d 834, 836 n.3 (1st Cir. 1998).

${ }^{138}$ But see supra note 21 (discussing the Third Circuit's unique interpretation of substantive due process).

${ }_{139}$ Bickerstaff Clay Prods. Co. v. Harris County, Ga., 89 F.3d 1481, 1490 (11th Cir. 1996) (citing Haw. Hous. Auth. v. Midkiff, 467 U.S. 229, 240 (1984)). 
ness. ${ }^{140}$ Hence, these threshold tests may not, in the end, favor either type of claim.

\section{Substantive Due Process Violations That Are Not Takings}

The converse, where due process affords a landowner greater substantive protection than does takings, is difficult to imagine. Such a case requires that substantive due process impose a more stringent test upon a regulation than does the Takings Clause.

Arbitrary and capricious SDP claims require a showing of arbitrary and/or capricious government action. ${ }^{141}$ However, this test is not independent of the means-ends analysis; it is merely another expression of rational basis review. ${ }^{142}$ As such, it imposes no conditions beyond this minimal means-ends test, and is therefore less stringent than the Agins "substantial relationship" test. Hence, it appears that takings law always provides a landowner at least as much, and sometimes more, substantive protection against confiscatory regulation as does substantive due process. ${ }^{149}$

\section{Remedial Differences}

At first glance, the remedies provided by the Takings Clause and by the Due Process Clause seem fundamentally different. Regulation that rises to the level of a taking is allowed by the Constitution; the Fifth Amendment merely requires that it be compensated. ${ }^{144}$ In contrast, the Fourteenth Amendment absolutely prohibits a regulation that deprives one of property without due process. "The remedy for a regulation that goes too far, under the due process theory, is not 'just compensation,' but invalidation of the regulation, and if authorized

140 The entitlement test serves as a threshold barrier for substantive due process claims, while ripeness requirements serve as a threshold barrier for takings claims. Simply because one may be considered "substantive" and the other "procedural" does not alter the gatekeeping effects of each.

${ }^{141}$ Supra note 21.

${ }^{142}$ Cf. Vill. of Euclid v. Ambler Realty Co., 272 U.S. 365, 395 (1926) ("[I]t must be said before the ordinance can be declared unconstitutional, that such provisions are clearly arbitrary and unreasonable, having no substantial relation to the public health, safety, morals, or general welfare."). The caselaw uses the tests interchangeably.

${ }^{43}$ However, at least one case has gone the other way. See Guimont v. Clarke, 854 P.2d 1, 16-17 (Wash. 1993) (holding that a violation of substantive due process, but not a taking, occurred when mobile home park owners were required by state statute to pay park residents forced to relocate when the owners closed their parks).

${ }^{144}$ Williamson County Reg'l Planning Comm'n v. Hamilton Bank, 473 U.S. 172, $194(1985)$. 
and appropriate, actual damages." 145

In practice, however, the distinction between the two remedies is less important than it might appear. First, monetary damages are often sought by substantive due process plaintiffs, like just compensation is sought by inverse condemnation (takings) plaintiffs. When money is the plaintiff's remedy of choice, however, there is no reason why the two causes of action need result in significantly different awards. ${ }^{146}$ Just compensation is, theoretically, the fair market value of the property taken. ${ }^{147}$

The damages available under substantive due process initially seem to have the potential to go far beyond fair market value to include recovery of costs incurred as a result of the improper government action and missed opportunity costs or profits. ${ }^{148}$ Opportunity costs and profits, however, are merely speculative to the extent they are not reflected in the fair market value of the property. ${ }^{149}$ Moreover, a successful substantive due process claim that recovers incurred costs as damages almost certainly is based upon a violation of state law (for example, a local zoning ordinance which is a violation of the state zoning enabling act), and the same damages for incurred costs may be

${ }^{145} I d$. at 197.

${ }^{146}$ See Benjamin, supra note 125, at 2670 ("[T] $[$ hough a damages award can differ in amount from just compensation, it is not clear there will be any significant disparity in actuality."). City of Monterey $v$. Del Monte Dunes illustrates the connection between takings claims and monetary damages:

Because its statutory action did not accrue until it was denied just compensation, in a strict sense Del Monte Dunes sought not just compensation per se but rather damages for the unconstitutional denial of such compensation. . . As its name suggests, then, just compensation is, like ordinary money damages, a compensatory remedy.

526 U.S. 687, 710 (1999).

${ }^{147}$ See United States v. Causby, 328 U.S. 256, 261 (1946) ("It is the owner's loss ... which is the measure of the value of the property taken [in a takings case]."); see also Katherine E. Stone \& Philip A. Seymour, Regulating the Timing of Development: Takings Clause and Substantive Due Process Challenges to Growth Control Regulations, 24 LOY. L.A. L. REV. 1205, 1207 (1991) (characterizing the remedy available in takings claims as "damages").

Substantive due process suits under $\$ 1983$ also afford a plaintiff the possibility of punitive damages and attorney's fees. Anderson, supra note 113, at 479-83. However, such awards are rare. But see Simi Inv. Co. v. Harris County, Tex., 236 F.3d 240, 255 (5th Cir. 2000) (awarding attorney's fees and implying that a successful $\$ 1983$ claim predicated on a violation of substantive due process might always be sufficient to warrant such an award).

${ }^{149}$ See Wheeler v. City of Pleasant Grove, 833 F.2d 267, 271 (11th Cir. 1987) (“ $[\mathrm{T}]$ he relevant fair market values by definition reflect a market estimation of future profits ...."). 
available under the substantive state law involved. ${ }^{150}$ Therefore, there is little reason why the amount awarded a plaintiff in a takings case should be any different from the amount in a substantive due process case. $^{151}$

Second, although a substantive due process plaintiff may seek to invalidate the government action, that remedy is also available for a takings plaintiff. ${ }^{152}$ If so, both types of plaintiffs would also be eligible for payment for the period during which the regulation was effective, the former as "damages" and the latter as compensation for a "temporary taking." 153

Third, it is not clear that most plaintiffs would necessarily prefer one remedy over the other if given an option. In fact, many substantive due process plaintiffs seek damages. Moreover, these claims are generally brought by developers who envision selling or leasing the property once it is developed. To such a developer, the property is a fungible investment. If the developer is compensated an amount equivalent to her profit, a takings remedy would put her (financially) in the same position as if the regulation were invalidated under substantive due process. Of course, there are other considerations that might influence an individual developer to favor one remedy or an-

${ }^{150}$ See Front Royal \& Warren County Indus. Park Corp. v. Town of Front Royal, Va., 135 F.3d 275, 278 (4th Cir. 1998) ("[G]overnmental actions that are violative of state law are properly challenged in state courts which exist, in part, to protect citizens from abuses of state law. Whether the Town illegally refused to comply with [state law] is not determinative of whether federal substantive due process has been violated." (citations omitted)).

${ }^{151}$ See Echeverria \& Dennis, supra note 39, at 708 ("[W] would provide a larger recovery is difficult to discern in the abstract."). But see Anderson, supra note 113, at 480-81 (noting potential reasons for differences between the two awards). One can easily imagine a developer who had considerable engineering, design, and legal expenses associated with a project, but who had not begun construction at the time a confiscatory regulation was imposed. In such a case, the developer could have potential damages far exceeding the value of the raw land. Yet Del Monte Dunes seems to include the value of such expenditures in the "just compensation" mandated by the Fifth Amendment. See 526 U.S. at 710 ("[I]n determining just compensation, the question is what has the owner lost, not what has the taker gained." (internal quotation marks omitted))

${ }_{152}$ In a takings claim, however, the government retains the option of invalidating the regulation, not the plaintiff. First English Evangelical Lutheran Church v. County of Los Angeles, Cal., 482 U.S. 304, 321 (1987); see id. ("Once a court determines that a taking has occurred, the government retains the whole range of options already available-amendment of the regulation, withdrawal of the invalidated regulation, or exercise of eminent domain."); see also Nollan v. Cal. Coastal Comm'n, 483 U.S. 825, 841-42 (1987) (granting injunctive relief for a taking by invalidating a condition on a building permit rather than requiring just compensation).

${ }^{153}$ First English, 482 U.S. at 318-19. 
other: whether the amount of compensation will indeed equal her potential profit, the uncertainty of the real estate market, the degree of opportunity cost and capital investment required to actually develop the property, the value to her reputation of completing a project, the relative time required to realize the two types of income, etc. Occasionally, a plaintiff who is herself the end user of the property might value the completed development much more so than its market value. ${ }^{154}$ Nevertheless, for the typical plaintiff, there is no overriding consideration that would cause her to favor being justly compensated over having the regulation invalidated and being permitted to proceed with development.

\section{Substantive Due Process Claims Should Not Lie in LAND DEVELOPMENT CASES}

The arguments against the use of substantive due process by land developers start with this seemingly self-evident lodestar: Lochner's economic substantive due process doctrine was and continues to be wrong. The Due Process Clause should not be read substantively, at least for property rights. But as the continued viability of substantive due process in land development cases suggests, this idea is perhaps not so self-evident after all.

If the emperor indeed has no clothes-if economic substantive due process is illegitimate per se-then the Graham doctrine is unnecessary. Alas, such may only be the case in the Seventh Circuit. ${ }^{156}$ The other circuits evidently require more normative reasons.

${ }^{154}$ Homeowners might value use of their property beyond its market value, but they bring takings or due process challenges to government regulation much less often than developers and commercial property owners. But see Vill. of Willowbrook v. Olech, 528 U.S. 562 (2000) (illustrating a homeowner's exaction claim made under equal protection); Waltz v. Town of Smithtown, 46 F.3d 162 (2d Cir. 1995) (illustrating a homeowner's substantive due process claim). Such suits are also occasionally brought by commercial landowners who are also the ultimate users of their property. See, e.g., Bickerstaff Clay Prods. Co. v. Harris County, Ga., 89 F.3d 1481 (11 th Cir. 1996) (illustrating a zoning challenge by a brick manufacturer who wanted to extract a mineral found on the zoned property).

${ }^{155}$ See, e.g., Phillips, supra note 4, at 956-60 (detailing reasons for overcoming majoritarian objections to economic substantive due process).

${ }^{156}$ Supra Part II.F. 


\section{A. Federal Courts Should Abstain from Considering Constitutional Claims by Land Developers}

The federal abstention doctrine set out in Burford $v$. Sun Oil Co. ${ }^{157}$ dictates circumstances under which a federal court with jurisdiction may refrain from deciding an issue in deference to state courts. Using Burford abstention,

a federal equity court ... may, in its sound discretion, ... "refuse to enforce or protect legal rights, the exercise of which may be prejudicial to the public interest"; for it "is in the public interest that federal courts of equity should exercise their discretionary power with proper regard for the rightful independence of state governments in carrying out their domestic policy." ${ }^{158}$

Burford abstention is generally reserved for cases in which a state has in place a complex administrative regulatory scheme (with state judicial review possible) in order to solve difficult problems that are primarily local in nature. This doctrine recognizes that sovereign states should be allowed to establish and conduct their own procedures for solving local problems without the heavy hand of the federal bench. Indeed, the interest of the states in such issues far outweighs the interests of the federal government. The doctrine also recognizes that judicial efficiency militates against federal intervention into issues routinely and competently handled by state regulatory procedures.

Local land use issues are the epitome of cases in which Burford abstention applies. ${ }^{159}$ Local land use decisions affect states far more than the federal government. States have established intricate, multilayered administrative and judicial systems for the making and evaluation of such decisions (often including zoning hearings, zoning appeals hearings, variance applications, de novo and appellate judicial review, and inverse condemnation proceedings). Allowing a disgruntled developer to short-circuit a state's carefully constructed decisionmaking mechanism by going to federal court with a substantive due process claim robs the state of "a sound respect for the independence

157319 U.S. 315 (1943).

${ }_{158}^{15}$ Id. at 317-18 (citations omitted).

${ }^{159}$ Pomponio v. Fauquier County Bd. of Supervisors, 21 F.3d 1319, 1327 (4th Cir. 1994) ("[W]e believe that in the usual case federal courts should not leave their indelible print on local and state land use and zoning law by entertaining these cases and, in effect, sitting as a zoning board of appeals."), disposition rev'd by Front Royal \& Warren County Indus. Park Corp. v. Town of Front Royal, Va., 135 F.3d 275, 282 (4th Cir. 1998). 
of state action." ${ }^{160}$ It is not surprising, therefore, that federal courts use Burford abstention doctrine for local land use issues, even when developers' constitutional rights are at issue. ${ }^{161}$

If there is any single area where the Federal Constitution and federal judiciary are unwelcome and meddlesome, it is in local land use and development decisions. Real property is uniquely local in character. The effects of its use or development are generally limited geographically, and its regulation is inherently a local matter. ${ }^{162}$ Regardless of one's view regarding whether developers need constitutional help or not, ${ }^{163}$ the invocation of the sledgehammer of federal judicial power is a particularly chilling control on the judgment of communities that better know local conditions and needs. The specter of the federal government's involvement in countless local land disputes takes our federalism beyond the bounds of reason. ${ }^{164}$ Moreover, the limited resources of federal courts themselves weighs against substantive due process rights for developers. ${ }^{165}$

Burford abstention is an equitable power of the federal courts, and it may not be invoked to dismiss a cause of action by a district court in a damage action. ${ }^{166}$ This is not an impediment to the use of Burford abstention where damages are sought, however, because the Court in Quackenbush pointed out that it was probably appropriate to use Burford to stay (rather than dismiss) federal proceedings until the state law issues were resolved in state court. ${ }^{167}$ Thus, even where a devel-

160 Burford, 319 U.S. at 334

161 See, e.g., MacDonald v. Vill. of Northport, Mich., 164 F.3d 964, 969 (6th Cir. 1999) (upholding Burford abstention by a federal district court where landowners brought a takings claim to enjoin public use of a right-of-way); Pomponio, 21 F.3d at 1328 (upholding Burford abstention for substantive and procedural due process and equal protection claims).

${ }_{162}$ Environmental regulation is perhaps a legitimate exception. It is distinguishable from other land development regulation because of its potentially widespread implications; it does not involve the kind of local (sometimes parcel-by-parcel) judgments required of zoning and other local controls.

${ }^{163}$ See, e.g., Stone \& Seymour, supra note 147 (concerning constitutional challenges to growth control through regulation).

${ }_{164}$ See Sullivan v. Town of Salem, 805 F.2d 81, 82 (2d Cir. 1986) (“[F] ederal courts should not become zoning boards of appeal to review nonconstitutional land use determinations by the circuit's many local legislative and administrative agencies.").

${ }^{165}$ While not all these federal constitutional claims need be made in federal court, most are.

${ }_{166}$ Quackenbush v. Allstate Ins. Co., 517 U.S. 706, 730-31 (1996) ("Burford might support a federal court's decision to postpone adjudication of a damages action pending the resolution by the state courts of a disputed question of state law.").

${ }^{167}$ Id. at 731 (dictum); see also Front Royal, 135 F.3d at 282 (stating that the Pom- 
oper's substantive due process claim sought damages, a federal court would be justified in invoking Burford abstention to stay the federal case until the developer brought and resolved a state inverse condemnation suit. Such a scenario is tantamount to dismissing the substantive due process claim: the delay likely will be too long and expensive, ${ }^{168}$ the substantive due process claim may become precluded, ${ }^{169}$ and the substantive due process claim will be more difficult to prove than the inverse condemnation claim. ${ }^{170}$ In effect, this is the approach taken by the D.C. and Sixth Circuits in imposing a takings-like ripeness requirement on substantive due process claims. ${ }^{171}$ Thus, whether or not the substantive due process cause of action seeks damages, the practical effect of Burford abstention is a dismissal of the substantive due process claim.

Of course, Burford abstention is discretionary on the part of district courts; it alone cannot forbid the federal judiciary from considering substantive due process claims by land developers. ${ }^{172}$ Nevertheless, the use of Burford abstention in zoning and land development cases illustrates the power of the argument that the federal judiciary has no place in deciding local land use policy and that economic substantive due process has no place in land development law.

\section{B. Graham Does Not Allow Substantive Due Process Claims by Land Developers}

Graham is a convenient "hook" from which might be hung the noose around Lochner's neck, ending the use of economic substantive due process by land developers. Graham and Albright recognized the principal that through

the specific guarantees of the various provisions of the Bill of Rights embodied in the first 10 Amendments to the Constitution . . . their Framers sought to restrict the exercise of arbitrary authority by the government in particular situations. Where a particular Amendment "provides an explicit textual source of constitutional protection" against a particular

ponio court should have stayed the action under Burford, not dismissed it).

168 See supra Part III.A.1 (noting the delay and cost of inverse condemnation suits).

${ }^{169}$ See supra Part III.A.2 (explaining that the resolution of takings claims often precludes later substantive due process claims).

${ }^{170}$ See supra Part III.B (discussing the more stringent elements of the takings means-ends analysis).

171 Supra Part II.D.

${ }^{172}$ It is also possible for substantive due process claims to be made against federal land use regulation, in which case Burford abstention (which requires deference to a state) would not apply. 
sort of government behavior, "that Amendment, not the more generalized notion of 'substantive due process,' must be the guide for analyzing these claims." ${ }^{173}$

Thus, the Graham doctrine provides that the specific remedies of the Bill of Rights are to be preferred over the "backstop" remedy of substantive due process.

On its face, this plain language seems to apply not just to criminal protections (as in Graham and Albright), but to the entire Bill of Rights. There is no reason to suspect that the Framers intended any different treatment for the Takings Clause; indeed, it is reasonable to believe that the doctrine is more applicable to takings than to criminal protections. Liberty interests (the category at stake in Graham and $A l$ bright) have received the most protection under substantive due process, yet liberty interests were still subject to the Graham doctrine in those cases. Property interests, which get much less protection under substantive due process, should therefore be much more susceptible to Graham. ${ }^{174}$

Graham prohibits any claim of substantive due process arising out of allegations implicating the Fourth Amendment's protections against the use of excessive force during an arrest or stop. ${ }^{175}$ Analogizing to takings, the Graham doctrine must apply not only to SDP takings claims, which exactly mimic takings claims, but also to arbitrary and capricious SDP claims, which arise out of the same nucleus of facts.

We need not worry that courts will use the Graham doctrine to reach out and invalidate other substantive due process claims in cases in which they are legitimately made. ${ }^{176}$ For example, in Moore v. City of East Cleveland, ${ }^{177}$ substantive due process was correctly applied to the liberty interest involved (the right to live with one's grandson) despite the fact that a property interest was also implicated (government restrictions on the use of one's home). The scope of Graham in the tak-

${ }^{179}$ Albright v. Oliver, 510 U.S. 266, 273 (1994) (quoting Graham v. Connor, 490 U.S. 386, 395 (1989)).

${ }^{174}$ See Vill. of Belle Terre v. Boraas, 416 U.S. 1, 13 (1974) (Marshall, J., dissenting) (stating that, had Boraas merely claimed violations of his property interests, without an equal protection claim, an arbitrary zoning ordinance would have been upheld because "[o] ur role is not and should not be to sit as a zoning board of appeals").

175490 U.S. at 395.

176 But see Toni M. Massaro, Reviving Hugo Black? The Court's "Jot for Jot" Account of Substantive Due Process, 73 N.Y.U. L. REV. 1086, 1101-03 (1998) (expressing this worry, particularly in homeowner takings cases).

${ }^{177} 431$ U.S. 494 (1977). 
ings context is easily limited to property interests, which are generally afforded protection by the Takings Clause. Liberty interests like that in Moore, which are not explicitly protected in the Bill of Rights, are not implicated by the Graham doctrine. Moreover, cases in which the decision maker acts unfairly toward a developer are better viewed as legitimate (i.e., procedural) due process cases rather than as arising under substantive due process.

Similarly, we need not worry that the scope of takings cases to which the Graham doctrine applies is too vague. ${ }^{178}$ The means-ends test for arbitrary and capricious SDP claims varies from the Agins test for a taking only in degree, not in character, so it is clear when Graham applies-whenever substantive due process is invoked to protect a real property interest. ${ }^{179}$

Nor will Graham reach out and eliminate equal protection. ${ }^{180} \mathrm{Fa}$ cially, the Graham doctrine applies to substantive due process only. Perhaps equal protection is vague, but the Graham doctrine is about eliminating unenumerated constitutional rights, not merely vague ones.

\section{Addressing the Doctrinal Critics}

A frequent criticism of the Graham doctrine is the idea expressed in United States v. James Daniel Good Real Property that where "the seizure of property implicates two 'explicit textual source[s] of constitutional protection,' ... [t] he proper question is not which Amendment controls but whether either Amendment is violated." ${ }^{\text {However, James }}$ Daniel Good was referring to Fourth and Fifth Amendment seizuressubstantive due process is hardly an "explicit textual source" of any-

${ }^{178}$ But see Massaro, supra note 176, at $1104-05$ (expressing this worry).

${ }^{179} C f$. County of Sacramento v. Lewis, 523 U.S. 833, 844 (1998) (holding that Graham does not foreclose a substantive due process claim when the Fourth Amendment is not implicated).

${ }^{180}$ But see Steven J. Eagle, Subsiantive Due Process and Regulatory Takings: A Reappraisal, 51 ALA. L. REV. 977, 1004 (2000) (arguing that the Equal Protection Clause is just as open-ended as the Due Process Clause and so may be equally susceptible to the Graham doctrine); Massaro, supra note 176, at 1100-02 (discussing the possible problems with Graham separating equal protection concerns from Takings Clause issues in housing code situations).

${ }_{181} 510$ U.S. 43,50 (1993) (quoting Soldal v. Cook County, Ill., 506 U.S. 56, 70 (1992)); see also Soldal, 506 U.S. at 70-71 (noting that "Graham does not bar resort . . to the Fourth Amendment's specific protection for 'houses, papers, and effects' rather than the general protection of property in the Due Process Clause"); Simi Inv. Co. v. Harris County, Tex., 236 F.3d 240, 248-49 (5th Cir. 2000) (rejecting the idea that the applicability of one constitutional amendment preempts the guarantees of another); Eagle, supra note 180, at 1004-05 (noting that "a litigant can claim rights under multiple constitutional provisions" under James Daniel Good). 
ubstantive due process is hardly an "explicit textual source" of anything. ${ }^{182}$ James Daniel Good is limited on its face to "the seizure of property" in criminal cases, whereas Albright extends the Graham doctrine to the Bill of Rights generally.

It has been proposed that the Takings Clause is the better rubric to challenge the burden placed upon an individual property owner by a regulation justified by a legitimate public purpose, and that substantive due process is the better rubric to challenge the public purpose itself. ${ }^{183}$ Thus, goes the argument, the two claims serve different functions and should coexist as independent causes of action. This argument, however, ignores the fact that the Takings Clause already includes a "public use" requirement. Although "public use" is a very low standard, it remains akin to the "legitimate governmental purpose" embodied in substantive due process. ${ }^{184}$ There is no substantive reason why government regulation needs to be measured against such an ends test in two separate contexts.

Others contend that substantive due process is the proper rubric under which to resolve issues of "private takings." 185 Since the Fifth Amendment explicitly addresses only "public purpose" takings and does not mention "private takings," the argument is made that the latter are addressed appropriately as questions of substantive due process, not takings. However, there are two distinct flaws in such an argument. First, it does not explain under what rubric private takings were prohibited before the Fourteenth Amendment was ratified in

${ }^{182}$ Indeed, Albright draws a sharp distinction between "“an explicit textual source of constitutional protection" and substantive due process. 510 U.S. at 273 (quoting Graham, 490 U.S. at 395).

${ }^{183}$ See Echeverria \& Dennis, supra note 39, at 719 ("Where . . the weight and significance of the governmental purpose is a relevant factor, the burden imposed by a government regulation should be subject to constitutional challenge, if at all, under the Due Process Clause.").

${ }^{184}$ See Haw. Hous. Auth. v. Midkiff, 467 U.S. 229, 240 (1984) ("The 'public use' requirement is thus coterminous with the scope of a sovereign's police powers."); Stone \& Seymour, supra note 147, at 1230 ("While regulations which fail to further any legitimate public purpose may well violate the constitution, it cannot logically be said that such regulations take property for the public benefit."); Summers, supra note 39, at 862 ("[The] public use requirement currently employed by the Court fails to serve any function that is not already satisfied by due process.").

${ }^{185}$ See, e.g., Anderson, supra note 113 , at 514 n.256 (noting that private takings "may be more appropriately treated under a substantive due process, rather than a just compensation, analysis"). A "private taking" is the government's confiscation of private property (or excessive regulation of its use) not for a public purpose, but rather for the benefit of another private entity. 
1868. ${ }^{186}$ Second, such an interpretation would lead to illogical and grossly unfair results. Imagine legislation requiring $A$, a wealthy homeowner, to give her home to $B$, a welfare recipient. If this argument prevailed, $A$ could not demand compensation because the legislation would not be subject to the Takings Clause because it is a private taking. Nor could $A$ invalidate the legislation on substantive due process grounds, since it is rationally related to a conceivably legitimate governmental purpose (helping the poor). The inescapable result is absurd.

Substantive due process proponents claim that improperly motivated government actions (e.g., maliciously targeted at individuals or designed to benefit the decision maker personally) are not necessarily takings and ought to be prohibited through substantive due process. ${ }^{187}$ This argument confuses substantive and procedural due process. ${ }^{188}$

\section{A World Without Substantive Due Process Rights for Land Developers}

The elimination of substantive due process rights would not be the bane of developers. Substantively, developers are better off with takings claims than with substantive due process claims. ${ }^{189}$ The minor differences in available remedies are generally not a significant issue. $^{190}$ Procedurally, the option of a jury trial, the wider choice of available fora, and the lack of preemption worries favor making a takings claim over making a substantive due process claim.

Nevertheless, for many developer plaintiffs, one factor overwhelms these advantages: a substantive due process claim is not subjected to the compensation prong of the Williamson County ripeness doctrine in most federal courts. ${ }^{191}$ However, SDP takings claims should be subject

${ }^{186}$ See, e.g., Calder v. Bull, 3 U.S. (3 Dall.) 386, 388 (1798) (disallowing "a law that takes property away from $A$ and gives it to B").

See, e.g., Stone \& Seymour, supra note 147, at 1231 \& n.171 (citing examples of malicious action by government against individuals); see also DeBlasio v. Zoning Bd. of Adjustment, 53 F.3d 592, 600-01 (3d Cir. 1995) (allowing a substantive due process claim against a decision allegedly influenced by the financial interest of a zoning board member's son).

${ }^{188}$ See Withrow v. Larkin, 421 U.S. 35 (1975) (considering the degree of bias permitted a state agency under procedural due process).

${ }^{189}$ Supra Part III.B.

${ }^{190}$ See supra Part III.C (explaining that the same monetary awards are generally available, that equitable relief is possible for both claims, and that there is no generallyapplicable reason for a plaintiff to prefer one over the other).

${ }^{191}$ But see supra Part II.D (noting that the Sixth and D.C. Circuits require a plaintiff to seek just compensation before making her substantive due process claims). 
to both the ripeness prongs of Williamson County. ${ }^{192}$ An SDP takings claim alleges that conduct that amounts to a taking must necessarily be a deprivation of property without due process. If that conduct does not rise to the level of a taking, then by definition an SDP takings claim cannot lie. A claim cannot rise to the level of a taking without meeting Williamson County's two-pronged ripeness test. Hence, the Williamson County test is also a prerequisite for an SDP takings claim. ${ }^{193}$

The advantage of arbitrary and capricious SDP claims over takings claims in terms of ripeness requirements is significantly offset by the other procedural and substantive advantages of a takings claim. Moreover, the mere fact that substantive due process plaintiffs enjoy a procedural advantage over takings plaintiffs is not by itself necessarily good policy, as illustrated by Burford abstention doctrine. ${ }^{194}$

\section{E. Where the Supreme Court May Go}

The Supreme Court has been silent on the use of substantive due process for land development rights and its relationship to regulatory takings. ${ }^{195}$ It remains justifiably fearful of giving judges the wide discretion represented by substantive due process. ${ }^{196}$ There is circumstantial evidence that developers' substantive due process rights are tenuous at best: the Court has refused to recognize the right, ${ }^{197}$ and the incorporation of a means-ends test into takings doctrine may be a precursor to the elimination of substantive due process for developers through the Graham doctrine.

Recently, however, the Supreme Court cast doubt on this circum-

192 If arbitrary and capricious SDP claims are allowed, however, there seems to be no reason to subject them to the compensation prong. Supra text accompanying notes 122-23.

${ }^{199}$ Without recognizing that an SDP takings claim existed, the Williamson County Court supported this position. "In sum, respondent's claim is premature, whether it is analyzed as a deprivation of property without due process under the Fourteenth Amendment, or as a taking under the Just Compensation Clause of the Fifth Amendment." 473 U.S. at 200.

194 Supra Part IV.A.

${ }^{195}$ See supra notes 56-57 (noting specific cases of the Court's reticence).

${ }^{196}$ See Collins v. City of Harker Heights, Tex., 503 U.S. 115, 125 (1992) ("As a general matter, the Court has always been reluctant to expand the concept of substantive due process because the guideposts for responsible decisionmaking in this unchartered area are scarce and open-ended.").

${ }^{197}$ See, e.g., supra note 57 (explaining how the Court ignored substantive due process arguments in Penn Central); supra text accompanying notes 35-37 (explaining the Court's disavowal of substantive due process in Euclid and Nectow). 
stantial evidence in deciding Easterm Enterprises v. Apfel. ${ }^{198}$ Eastern Enterprises was the former owner of a coal mining business. Eastern (and the rest of the industry) agreed to provide medical insurance to its retirees as long as it remained in the coal business, but in 1985 it sold its coal mining operation. As the industry shrunk and more coal mines went out of business, the number of retired miners who were "orphaned" without benefits grew dramatically. Congress sought to solve the problem by passing the Coal Act, ${ }^{199}$ which spread the burden of caring for all the "orphaned" miners upon former industry players such as Eastern Enterprises. Eastern's obligation under the Coal Act was a staggering fifty to one hundred million dollars.

Eastern Enterprises claimed that the Coal Act was both a taking and a violation of its substantive due process rights. The First Circuit considered both arguments, but upheld the Act. ${ }^{200}$

The Supreme Court reversed in a five-to-four decision. ${ }^{201}$ A plurality of four analyzed the Coal Act under the Takings Clause and found that it had been applied unconstitutionally to Eastern Enterprises. The four dissenters analyzed the Act as a substantive due process case and found it to have passed muster. Justice Kennedy concurred with the plurality that the Coal Act unconstitutionally burdened Eastern Enterprises, but he reached his decision using a substantive due process analysis. ${ }^{202}$ Hence, although there was a majority of five for the proposition that the Coal Act was applied unconstitutionally to Eastern, there was also a majority of five for the proposition that the case was an issue of substantive due process, not of a taking. In this respect, Justice Kennedy's opinion, which was subscribed to by no other Justice, may nevertheless represent the majority view. ${ }^{203}$

Although seeming to give a boost to substantive due process, this type of plurality decision is perhaps best viewed as narrowly applicable

198 524 U.S. 498 (1998).

199 Coal Industry Retiree Health Benefit Act of 1992 (Coal Act), 26 U.S.C. $\$ \S 9701$ 9722 (1994).

${ }^{200}$ E. Enters. v. Chater, 110 F.3d 150 (1st Cir. 1997), rev'd sub nom. E. Enters. v. Apfel, 524 U.S. 498 (1998). This was a year before the First Circuit held that substantive due process claims would not lie when a "garden-variety regulatory takings claim" was possible. S. County Sand \& Gravel Co. v. Town of South Kingstown, 160 F.3d 834, 835 (1st Cir. 1998).

${ }^{201}$ E. Enters. v. Apfel, 524 U.S. 498 (1998).

${ }^{202} I d$. at 538-39 (Kennedy, J., concurring in the judgment and dissenting in part).

${ }^{203}$ See Eagle, supra note 180, at 988 (likening Justice Kennedy's opinion to Justice Powell's opinion in Regents of the University of California v. Bakke, 438 U.S. 265 (1978)). 
only to its particular facts. ${ }^{204}$ The facts of Eastern Enterprises, in which an obligation to pay pecuniary retirement health benefits was at stake, are easily distinguished from land use regulation cases. Indeed, both Justice Kennedy $^{205}$ and the dissenters ${ }^{206}$ seem to have based their application of substantive due process on the fact that no specific property interest (like the right to develop a particular lot) was "taken"; instead, the obligation imposed upon Eastern Enterprises was a general one reaching all the company's property. Therefore, Eastem Enterprises is distinguishable from land development cases and is no barrier to the elimination of substantive due process claims in that context.

Perhaps the Supreme Court has resurrected economic substantive due process within the Takings Clause. If so, that will be a battle for another time. At present, there is no need for another source of such protection for land developers in the Due Process Clause of the Fourteenth Amendment.

\section{CONCLUSION}

Economic substantive due process, long thought extinct, actually lives on like an endangered species isolated on the island of real property law. The Graham doctrine, however, affords an opportunity to extirpate this final species of the Lochner era, yet do so without significant harm to the rights of developers. With the incorporation of a means-ends test into regulatory takings doctrine, economic substantive due process is no longer rationally related to any legitimate legal purpose. five Justices, 'the holding of the Court may be viewed as that position taken by those Members who concurred in the judgment on the narrowest grounds . ..." (quoting Gregg v. Georgia, 428 U.S. 153, 169 n.15 (1976))).

${ }^{205}$ E. Enters., 524 U.S. at 540 (Kennedy, J., concurring) ("Our cases do not support the plurality's conclusion that the Coal Act takes property.").

${ }_{206} I d$. at 554-55 (Breyer, J., dissenting) ("The Constitution's Takings Clause does not apply."). 
